\title{
Groundwater calcrete aquifers in the Australian arid zone: the context to an unfolding plethora of stygal biodiversity
}

\author{
W.F. Humphreys \\ Western Australian Museum, Francis Street, Perth, Western Australia 6000, Australia
}

\begin{abstract}
The Western Shield of Australia has been above sea level since the Palaeozoic. It is incised by ancient palaeovalleys now containing ground water calcretes that are found throughout much of arid Australia. The calcretes are deposited, owing to surface evaporation, from a groundwater flow path that increases in salinity from fresh to hypersaline groundwater each terminating at a salt lake (playa). The calcrete aquifers contain a diverse obligate groundwater fauna (stygofauna: predominantly Crustacea) in one of the oldest non-marine landscapes on Earth. Each of the 11 calcrete areas examined so far contains a unique fauna; there are over 210 large discrete calcrete bodies in the Western Australian arid zone. This paper examines a working hypothesis that the stygofauna became isolated in the upper tributaries of the palaeodrainage systems by the progressive upstream movement of salinity from the Eocene onwards. Although each calcrete body does have a unique fauna, as predicted by the hypothesis, the hypothesis has proved too simple because the hydrochemical cycles are repeated along the length of the palaeochannels, each terminating in a saltlake immediately downflow of the calcrete. A new hypothesis has to incorporate these intervals of hypersaline groundwater/calcrete discontinuities acting as barriers to dispersal of the stygofauna. The paper focuses on the geological and landscape setting, and the hydrochemical and groundwater context in which this stygal diversity is found. It is intended to serve as a background resource for further work on this diverse stygofauna. A synopsis is provided of the knowledge of this stygofauna. The presence of such highly diverse and locally endemic stygofauna, often ancient relictual lineages, in a major economic resource within arid Australia poses delicate and challenging conservation issues. At the same time the scientific challenge is considerable to understand the development and functioning of these systems in order that they can be managed sustainably.
\end{abstract}

\section{INTRODUCTION}

The magnitude of the biodiversity present in subterranean waters has only recently been given prominence (Marmonier et al., 1993). In a global context, the groundwater fauna of Australia (along with that of Africa) is especially poorly known (Marmonier et al., 1997); and that mostly from the investigation of cave faunas (Eberhard et al. 1991; Eberhard and Spate, 1995; Humphreys, 1993, 2000a; Thurgate et al., this volume). Nonetheless, Australia, especially the northwestern part, has unexpectedly come to the attention of stygobiol-ogists and systematists on account of the diverse obligate groundwater fauna (stygofauna) that is being found in the region (e.g. Humphreys, 1993, 1999a, 1999b; Wilson and Keable, 1999; Wilson and Johnson, 1999; Bradbury and Williams, 1996a, 1996b, 1997a, 1997b; Pesce et al., 1996a, 1996b; Pesce and De Laurentiis, 1996; De Laurentiis et al., 1999). This includes a number of higher order taxa variously new to science (undescribed family of flabelliferan
Isopoda: Wilson and Ponder, 1992), new to the southern hemisphere (Thermosbaenacea: Poore and Humphreys, 1992; Remipedia: Yager and Humphreys, 1996; Danielopolina: Danielopol et al. 2000; Epacteriscidae: Jaume and Humphreys, 2001), or new to Australia (Spelaeogriphacea: Poore and Humphreys, 1998; Stygocyclopia: Pseudocyclopiidae, Jaume et al. 2001). Many of these taxa occur in near coastal and anchialine waters and are interpreted as comprising a relictual tethyan fauna, several lineages of which have congeneric species known elsewhere only from subterranean waters on either side of the North Atlantic - the northern Caribbean region and the Balearic and Canary archipelagos (Humphreys, 1993, 1999a; 2000a; Jaume and Humphreys, 2001; Jaume et al. 2001).

The history of these anchialine ecosystems, mostly in Tertiary rocks, stands in marked contrast to that of inland aquifers on the elevated Precambrian shield. Areas presently land that were ever covered by the 


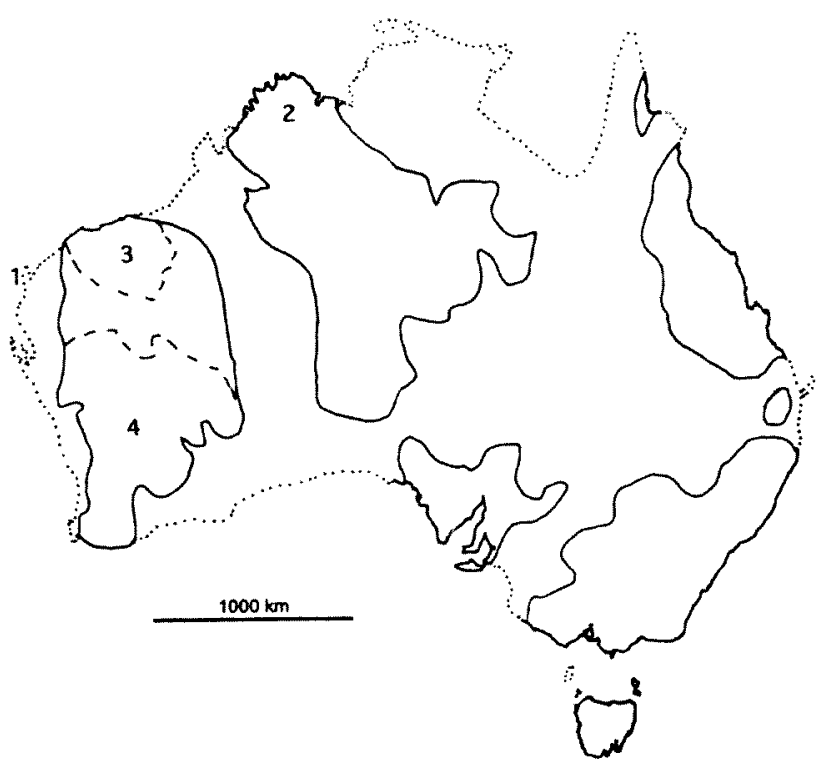

Figure 1 The current outline of Australia superimposed on the areas continually emergent since the Proterozoic. 1. Cape Range; 2. Kimberley; 3. Pilbara; 4, Yilgarn. The solid line encircling the numbers 3 and 4 encompasses much of the Western Shield. Derived from data in BMR Palaeogeographic Group (1990)

sea, even as far back as the Mesozoic, often contain communities of obligate subterranean aquatic species of formerly marine lineages 'stranded' inland by marine recession (Stock, 1980; Boutin and Coineau, 1990; Notenboom, 1991; Holsinger, 1994), particularly in karst areas. This is especially notable in regions that have undergone substantial orogenesis (Messouli et al., 1991; Boutin, 1993). While such areas occur in Australia (orogenic: Humphreys, 1993; stranded: Bradbury and Eberhard, 2000), large parts of Australia have not been inundated by the sea since at least the Palaeozoic (Figure 1), including the Pilbara and Yilgarn Cratons of Western Australia and their associated orogens that collectively may be referred to as the Western Shield (Beard, 1998). These regions of Precambrian rocks are covered by only a thin regolith and seem, on first principles, to proffer poor prospects for the exploration of stygal biodiversity.

This stable, truly continental area of Australia has a non-marine, presumably freshwater history extending though several geological eras. Here, I present a synopsis of the geological and tectonic history of the area and provide the geological and hydrogeochemical context pertinent to the interpretation of biogeographical hypotheses relating to stygofauna. The stygofauna of this region is discussed in general terms, showing the pattern of its distribution and processes that could cause vicariance in stygal lineages.

\section{BIOGEOGRAPHIC HYPOTHESES}

The following hypotheses developed progressively.

1. The occurrence of diverse stygofaunas in the Australian arid zone (Humphreys, 1993, 2000a) suggest that other arid regions of Australia should contain stygofaunas relictual from more humid periods.

2. On areas not covered by the sea since the Palaeozoic the stygofauna will include ancient freshwater lineages.

3. Headwater aquifers within single palaeodrainage channels are likely to contain distinct but related faunas. Owing to the progressive onset of aridity such stygofauna will likely be isolated in the fresh groundwater aquifers in the upper tributaries of the palaeodrainage systems. The inland (easterly) draining palaeodrainage channels of the Western Shield are generally saline but the upper tributaries contain fresh groundwater in places (D.P. Commander, personal communication, 1997). This fresh groundwater in the upper reaches would have been progressively isolated from adjacent freshwaters due to the upstream encroachment of salinity following the onset of arid conditions in the Eocene. Hence, the groundwater fauna that may inhabit such an aquifer would likely be distinct from those in other headwater aquifers, even within the same palaeodrainage channel (developed below).

4. The numerous groundwater calcrete aquifers in the Australian arid zone may contain separate faunas. This was suggested by the finding of a rich stygofauna, with Gondwanan affinities, in a single calcrete aquifer in the Pilbara isolated by groundwater divides and water gaps from adjacent aquifers (Poore and Humphreys, 1998). Hence, these aquifers had the potential to contain substantial biodiversity (Humphreys, $1999 \mathrm{~b}$ ) of both macroinvertebrates and meiofauna, including higher order taxa of a relictual nature (Poore and Humphreys, 1998).

5. Stygofauna may be 'older' than the matrix in which they occur (cf. Cape Range anchialine system where the community composition comprises lineages in which global scale vicariance is likely to have occurred long before the formation of the Tertiary strata in which they occur: Humphreys, 2000a, 2000b).

\section{POTENTIAL ISOLATING FACTORS}

The hyporheic zone (the underflow and bankflow of rivers) serves both to protect its inhabitants from extremes of temperature, desiccation and discharge (Ward, 1992), and as an aquatic refuge 
during droughts (Williams, 1977; discussion in Brunke and Gonser, 1997: 16). Furthermore, it includes the ecotone between surface and groundwaters and thus provides a window between the two ecosystems (Gibert $e t$ al., 1997) for the movement of nutrients, organic matter, pollutants and biota, either from groundwater to surface water, or vice versa depending on the relative piezometric (water pressure) heads.

The major river systems that incised their valleys into the Precambrian basement to form the current palaeodrainage system of the Australian arid zone, by analogy with other modern major drainages, would have been freshwater systems containing a suite of epigean and hyporheic communities having some coherence along the length of the drainage (Dole-Olivier et al, 1994; Ward and Voelz, 1994). This results from the connectivity of the hyporheic corridor providing a dispersal route for meiobenthic taxa along a continuous alluvial aquifer system (Stanford and Ward, 1993), which in the long term is probably interconnected with other catchments (Ward and Palmer, 1994).

With the onset of aridity a waterway would have become progressively more saline, with the salinity being greater downstream owing to cumulative effect of evaporation along the length of the river. With this developing salinity, communities comprising freshwater lineages would have contracted upstream eventually being confined to the headwaters, which remained fresh (e.g. crangonyctoid and bogidiellid amphipods). Meanwhile marine lineages (e.g. melitid and ceinid amphipods) may have moved upstream from the coast (Figure 2), assuming no insurmountable barriers to migration, such as water gaps (Poore and Humphreys, 1998). As the aridity deepened, groundwater would have become the principal

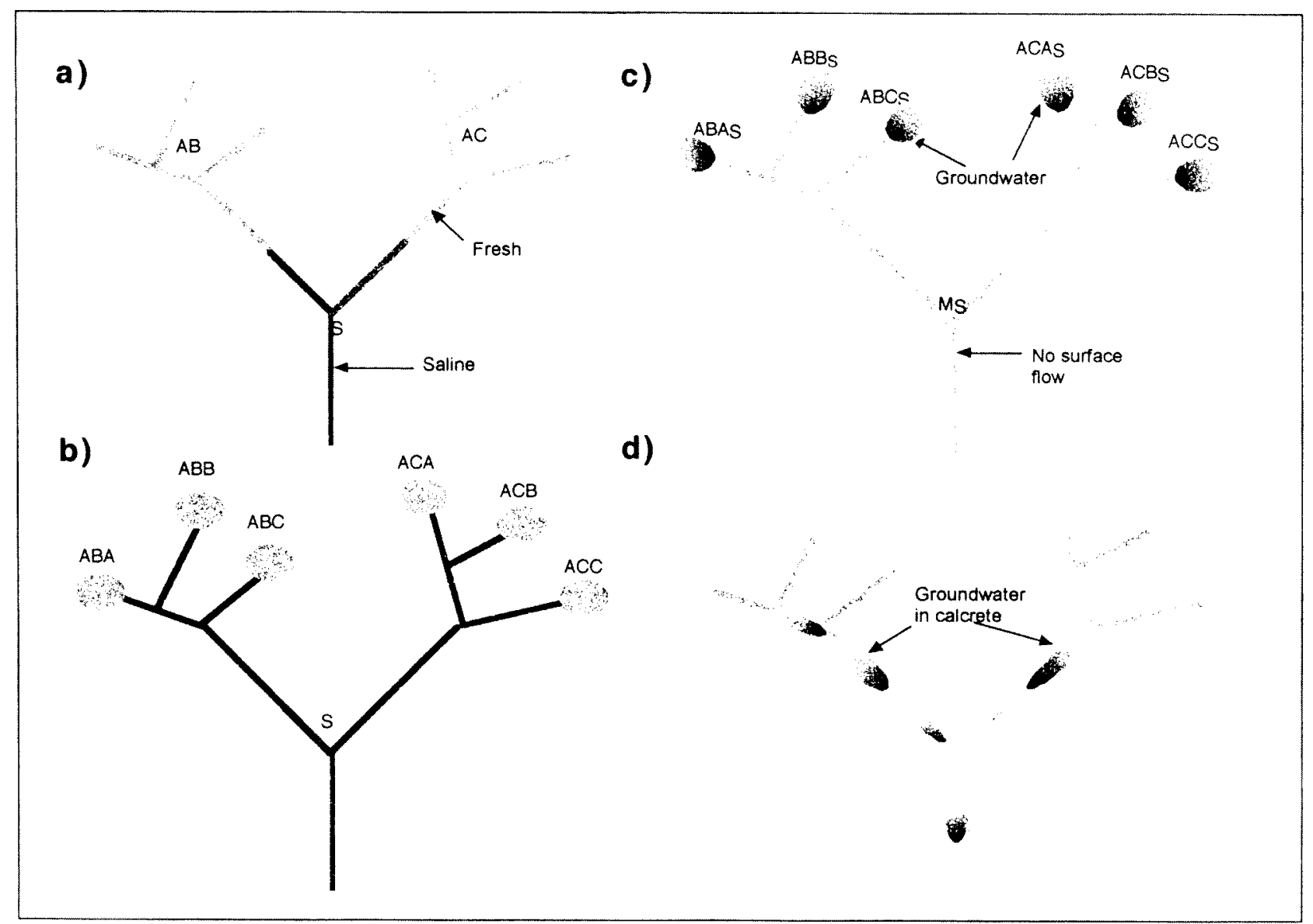

Figure 2 Hypothetical model showing the distribution of fresh and saline waters in a catchment with the progressive onset of arid conditions on a formerly humid system and the isolation of faunistic lineages: a) the onset of salinity (darker shading) in a catchment containing freshwater fauna lineage A (e.g. crangonyctoid Amphipoda or Bathynellacea) isolated into two tributaries giving $A B$ and $A C$, a marine lineage $M$ invades saline waters (e.g. ceinid Amphipoda); b) salinity progresses upstream restricting freshwater to the headwaters of tributaries further isolating lineage $A$ producing gene pools $A B A, A B B \ldots . A C C ; c)$ with increasing salinity surface flow ceases and perennial fresh water is principally underground in the upper tributaries producing isolated gene pools in stygofauna $\left(\mathrm{ABA}_{\mathrm{s}}, \mathrm{ABB}_{\mathrm{s}} \ldots . \mathrm{ACC}_{\mathrm{S}}\right.$ and marine lineage $\left.\mathrm{M}_{\mathrm{s}}\right)$; $\left.\mathrm{d}\right)$ the current situation with a series of hydrogeochemical cycles in groundwater repeating down the length of the palaeodrainage system - Morgan's Model- forming groundwater calcrete bodies within which there is a gradient of salinity both vertically and along the flow line. 
permanent waters remaining throughout the region. Repeated invasion of groundwater habitats (Culver et al., 1995) can be expected to have accompanied this process. In such a model (Figure $2 \mathrm{a}-\mathrm{c}$ ) the sequence of isolation (vicariance) should be identifiable from the cladogenic events in the stygofauna.

\section{Geology}

\section{Playas and palaeodrainage}

The strings of salt lakes, or playas, that form such a prominent part of the landscape in the more arid parts of Australia mostly occur on Precambrian basement rocks (Figure 4 in van de Graaff et al., 1977) and in areas of internal drainage (Figure 1 in ibid.). The playas are the surface manifestation of palaeodrainage channels, rivers that largely stopped flowing when the climate changed from humid to arid in the Palaeocene (Bowler, 1976). The palaeodrainage channels in the Yilgarn were deeply incised into a plateau of Precambrian rocks prior to the break-up of Gondwana, perhaps as early as the Permian. Towards the south, minor palaeodrainage lines probably formed after the uplift of the Darling Plateau, and marine transgressions in the Eocene deeply penetrated the palaeovalleys along the western margin of the Eucla basin (Jones, 1990; L. Worrall, CRCAMET, CSIRO, personal communication 1998) when conditions were tropical. While the development of these palaeodrainage lines has considerable antiquity, the overall drainage system seen today probably developed in the Late Cretaceous (Morgan, 1993; BMR Palaeogeographic Group, 1990: 82).

\section{Calcrete formation, occurrence and age}

The long period of emergence and the ensuing prolonged erosion down to the Precambrian basement has resulted in classical karst terrain being absent from the Western Shield. However, carbonate deposits are widespread throughout the arid zone both as soil and groundwater calcretes (Arakel, 1996). Groundwater or valley calcretes (hereafter termed calcrete) are carbonate deposits whose formation is directly associated with groundwater, rather than with soil development (pedogenic calcrete). These carbonate deposits, generally in the order of $10 \mathrm{~m}$ thick, form near the water table of shallow aquifers in arid lands as a result of concentration processes by near-surface evaporation (Jacobson and Arakel, 1986). They are especially important in the Australian context (Figure 3) as they form in arid climates (annual rainfall $<200 \mathrm{~mm}$ ) with high potential evaporation (>3000 mm per year: Mann and Horwitz, 1979). They occur where the movement of the groundwater is slow and where the rainfall is episodic resulting in substantial fluctuations in the water table. Groundwater calcretes often develop

Table 1 Calcrete aquifers containing stygofauna sampled in the Western Shield and adjacent regions. Information on the aquifers is contained in the references cited. The numbers denote locations shown in Figure 3 . - denotes calcretes that overlie Proterozoic Wittenoom Dolomite containing solution channels in the upper horizons.

\section{Pilbara}

Fortescue Catchment
1. - Western Fortescue Plain ${ }^{1}$
2. Ethel Gorge
3. Weeli Wolli
4. - South Fortescue

Ashburton Catchment

4. Hardey River

Ashburton Plain
5. Robe River ${ }^{1}$
6. Fortescue River

\section{Yilgarn}

Western drainage

7. Austin Downs

8. Cue

Eastern drainage
9. Paroo
10. Lake Violet
11. NE Lake Way
12. Hinkler Well
13. Windarra

Millstream Dolomite (Barnett and Commander, 1985)

Woodward-Clyde, 1997b; BHP, 1997.

Woodward-Clyde, 1997a

Hamersley Iron, unpublished reports Tom Price Water Supply

Hamersley Iron, unpublished reports Tom Price Water Supply

Commander, 1994a

Commander, 1994b

Big Bell Mine, unpublished reports personal observation

Sanders, 1973

Wiluna Gold Mine, unpublished reports

EPA, 1981; Passmore, 1983.

Mann and Deutscher, 1978; Mann and Horwitz, 1979

Maczurad and Murphy, 1997.

1 The Western Fortescue Plain catchment, previously draining down the Robe River, was captured from the northwest by the Fortescue River at the end of the Pleistocene or Holocene (Barnett and Commander, 1985). 


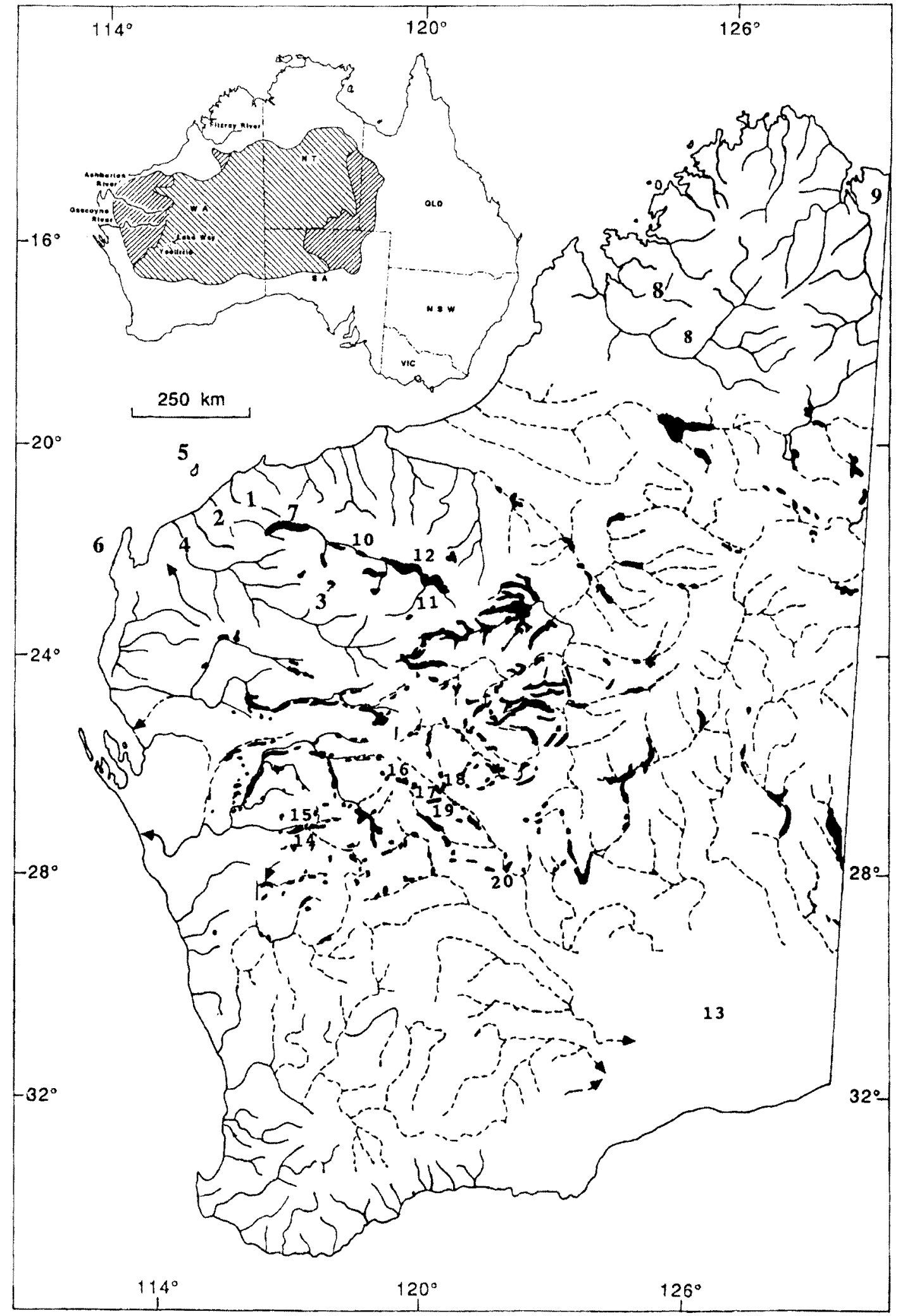

Figure 3 The distribution of groundwater calcrete aquifers in Western Australia. Modern and palaeo- drainage (respectively continuous and dashed lines) and calcrete areas (black) are shown. Derived from data in Geological Survey $(1989,1990)$, drawn by Julianne Waldock on a base map provided by Philip Commander. Inset: general distribution of groundwater calcretes in mainland Australia, adapted from Mann and Horwitz (1979). 1, Fortescue River; 2, Robe River; 3, Hardey River; 4, Ashburton River; 5, Barrow Island; 6, Cape Range; 7, Millstream (northern edge of the Westem Fortescue Plain aquifer; 8 , Kimberley Devonian reef system between the 8's; 9 . Ningbing Range, an outlier of $8 ; 10$, Mulga Downs; 11, Ethel Gorge near Newman; 12. Fortescue Marsh; 13, Euda Basin; 14, Lake Austin; 15, Cue; 16, Paroo; 17, Lake Violet; 18, NE Lake Way; 19, Hinkler Well; 20, Windarra, The Carey palaeodrainage channel lies between Paroo and Windarra. 
typical karst features (Sanders, 1974; Barnett and Commander, 1985) with sinkholes serving as major recharge zones for the aquifers. Well developed karst has interconnected phreatic conduits providing attributes that make the aquifer suitable both for the exploitation for groundwater and as potential stygofauna habitat. The calcrete bodies considered in this paper are shown in Table 1 with sources of information as to their characteristics.

In the Lake Way and Lake Miranda areas, shallow aquifers occur in lacustrine, aeolian and alluvial/ colluvial clay sand deposits, often incorporating gypsum and calcrete deposited by the groundwater (Arakel et al., 1990). The deep aquifers that occur in older calcretes beneath the playa lake facies appear to be interconnected and truncate into Tertiary lateritized terrain (Arakel et al., 1990). The sediments infilling the palaeochannels are mostly Eocene or later but the age of the calcretes is unknown. The extensive alluvial fan calcretes and some of the river valley calcretes formed in the Oligocene (37-30 million years ago) may have following the onset of the continental aridity (Morgan, 1993). Many of the calcrete areas, especially those north of $31^{\circ} \mathrm{S}$, are being actively deposited and the others have probably been remobilized and redeposited (Morgan, 1993), attributes that make the dating of calcrete deposits using standard radiometric methods problematic.

\section{Hydrology}

There are a number of processes and events which have impinged at various times on the hydrology of the Western Shield and which may have affected the hydrological continuity within the region. These may have permanently isolated some stygal lineages or else permitted faunas to coalesce: these factors are discussed in the following sections.

The Western Shield has been tectonically stable and continuously emergent above the sea since at least the Palaeozoic. At times of high sea level, such as the Eocene (52-37 million years), a relative sea level rise of about $300 \mathrm{~m}$ flooded the downstream ends of the palaeorivers. The region was penetrated deeply along the south-western palaeochannels, as far north as c. $30^{\circ}$ south. The inland distribution of Thermosbaenacea, which in the Robe River stops at c. $300 \mathrm{~m}$ altitude, may reflect this marine incursion. Hence, processes and events occurring throughout the Eocene that may have facilitated or caused the isolation or merging of gene pools are pertinent to the distribution and evolution of the stygofauna within the Western Shield. These processes and events are distinct from the plate tectonic events, such as the progressive fragmentation of Pangaea and Gondwana, factors which together with the Cretaceous and Tertiary marine incursions, more broadly delineated the distribution and composition of the ancient freshwater stygal lineages of Western
Australia. These events are reflected, for example, in the distribution of the Phreatoicidea (Wilson and Keable, 1999), Spelaeogriphacea (Poore and Humphreys, 1998), Amphipoda (Bradbury and Williams 1997a), and the anchialine fauna of the northwest coast (Humphreys, 2000a; Jaume et al., 2001).

\section{Water gaps and groundwater divides}

The Robe and Fortescue, which together drain the Western Fortescue Plain (Millstream), flow through one or more water gaps to the west due to incision of a superimposed drainage (Kriewaldt and Ryan, 1967) into the Precambrian basement, as do other rivers draining the western Pilbara. The Proterozoic bedrock at the water gaps is effectively a groundwater hydrological boundary to the west. A groundwater divide within the Western Fortescue Plain occurs between the Robe and Fortescue Rivers, while upstream, the groundwater of the Fortescue River flows towards the Fortescue Marsh (Barnett and Commander, 1985). In consequence, the stygal ecosystem in the Western Fortescue Plain is currently probaly a groundwater island, the age of which is unknown. However, in more humid times, the water balance could well have resulted in unidirectional groundwater drainage in the Fortescue Valley.

The Western Shield is divided from north to south by a drainage divide that separates those catchments draining to the Indian Ocean, some still active rivers, from those draining to the east which are now largely inactive and disorganised (Beard, 1998). The present drainage is superimposed on a much larger palaeodrainage system incised into Precambrian rocks and formed during the Mesozoic when the Western Shield was attached to Antarctica (van de Graaff et al., 1977; Morgan, 1993; Beard, 1998).

The central watershed traverses a palaeosurface barely modified since the Cretaceous (Beard, 1998). This central watershed is of fairly uniform elevation traversed only by a few minor gaps or low points that may be indicative of a change to the drainage patterns in the distant past. On Killara Station, a col 50-100 m below the level of the adjacent watershed, which separates the Murchison and Carey palaeodrainage systems, is the most prominent of these (Beard, 1998). All Australian stygal diving beetles (Dytiscidae: see below) known to date are from these two adjacent palaeodrainage systems but no others drainages have been examined in the Yilgarn. While invoking some significance of this geomorphological gap to the biogeography of the beetles is tempting, this minor gap may merely reflect the trend of less resistant Proterozoic rocks (Beard, 1998). Examination of sympatric taxa from ancient freshwater lineages, for example crangonyctoid amphipods or bathynellid syncarids, 


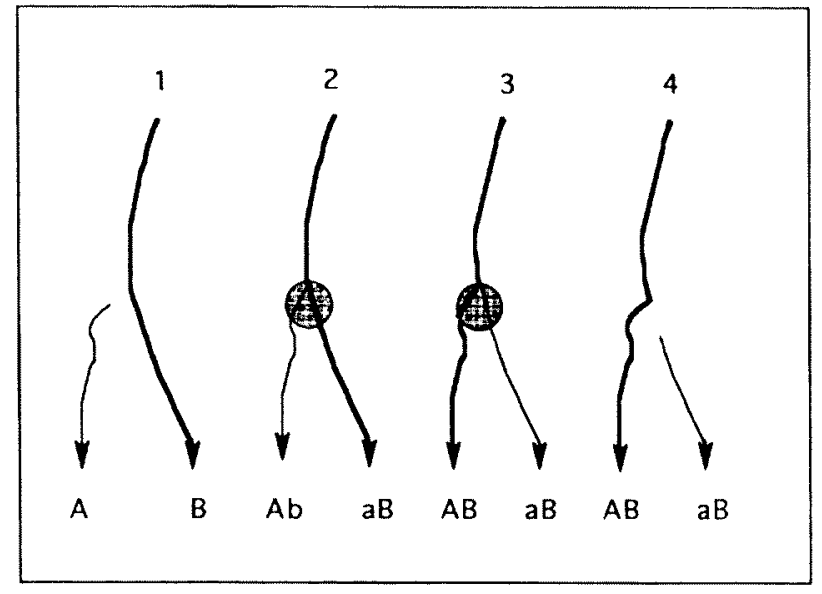

Figure 4 Hypothetical fauna mixing by river capture through times 1 to 4 . The initial faunal assemblages $A$ and $B$ in the separate rivers partially merge during the process of river capture (circle); whereas the capturing river becomes a complete mix of $\mathrm{A}$ and $\mathrm{B}$. The beheaded river remains predominantly $B$ with a fraction of $A$ (denoted ' $a$ ').

would make a substantial contribution to this discussion.

Groundwater faunas may merge or become isolated by long term fluviogenic processes. The lower reaches of a river, or the groundwater aquifers, may become isolated from the original catchment by river capture. This occurred in the lower Robe River, the former drainage of which was captured by the Fortescue River at the end of the Pleistocene or early Holocene (Barnett and Commander, 1985). Alternatively, isolation may result from the redirection of river flow such as occurred in the lower Ord River (Carroll, 1947) where the main flow through the Cave Spring Gap was diverted to its present course. In such cases, the fauna of the captured and capturing sections of the river should mix so that the now isolated lower section of the captured river will contain a representation of the original main stream. The faunal integrity of this will depend on the temporal and spatial extent of the window of opportunity for faunal mixing provided during the process of river capture (Figure 4).

\section{Hydrogeological model}

In the Yilgarn, groundwater calcretes form along a hydrogeological gradient, originally characterized from the Hinkler Well calcrete to the west of Lake Way, along the drainage line of which there is a succession of chemical precipitations associated with increasing salinity (Mann and Deutscher, 1978; Mann and Horwitz, 1979). Carbonate is deposited in the mid-line of the drainage with associated silcrete and celestite. Downstream, aeolian deposits of gypsum occur with sepiolite and aragonite on the shores of the salt lake and on the bed of which halite is found. Upstream of the 'chemical delta', the calcrete is underlain in places by ferricrete and laterite, thought to have formed in more humid climates during the Miocene (Mann and Horwitz, 1979).

Morgan (1993) generalising from the studies of Mann and Deutscher (1978) and Mann and Horwitz (1979) on the Hinkler calcrete. described a model for the development of repeated groundwater calcretes and salt lakes along the length of the palaeodrainage systems. The processes involved differ on either side of the Menzies line, where northern acacia scrub (mulga: Acacia aneura F. Muell. ex Benth.) gives way to Eucalyptus spp. scrub (also known as the mulga/eucalypt line: Butt et al., 1977), which marks the change of climate from winter dominant rainfall to a more semi-arid mixed winter and summer rainfall region. In the Yilgarn, this latitude (c. $29^{\circ} 30^{\prime} \mathrm{S}$ ) approximates the southem limit of valley calcretes (Morgan, 1965).

In the Oligocene (37-30 mybp) valley calcretes extended further south but they retreated as a result of later geochemical conditions that affected the reactions between groundwater and river channel sediments. North of latitude $30^{\circ} \mathrm{S}$, the palaeorivers are characterised by the development along their length of separate hydrogeochemical systems associated with the formation of each salt lake or playa. As salinity increases there is a well defined change in groundwater chemistry (Figure 5). The changes take place between widely separate intake and outflow locations and is also related to the duration of flow of the groundwater. Hence, this increase in salinity of the groundwater and the relative change in chloride: sulphate has both a spatial and temporal dimension.

This hydrochemical trend is initiated at the headwaters of each recharge system, such as a large alluvial fan, and the cycle is terminated at the evaporation outlet marked by the lower boundary of the calcrete with a salt lake. The low salinity waters (500-2000 $\mathrm{mg} \mathrm{L}^{-1}$ TDS: total dissolved solids) near the intake are alkaline and rich in bicarbonates. The groundwater interacts with the sediments along its flow path and as a result becomes less alkaline, increases markedly in salinity, and changes to a chloride-sulphate type. In the groundwater, a well defined change in common ion ratios develops with increasing salinity, marked especially by a relative increase in chloride and sulphate with respect to other ions. This, in itself, may contribute to the heterogeneity in stygofauna distribution within a given calcrete area reported by Poore and Humphreys (1998). The calcretes pass downstream into dolomites then into gypsum and halites in waters from 20,000 to over $200,000 \mathrm{mg} \mathrm{L}^{-1}$ TDS. The main channel calcretes are formed at the 


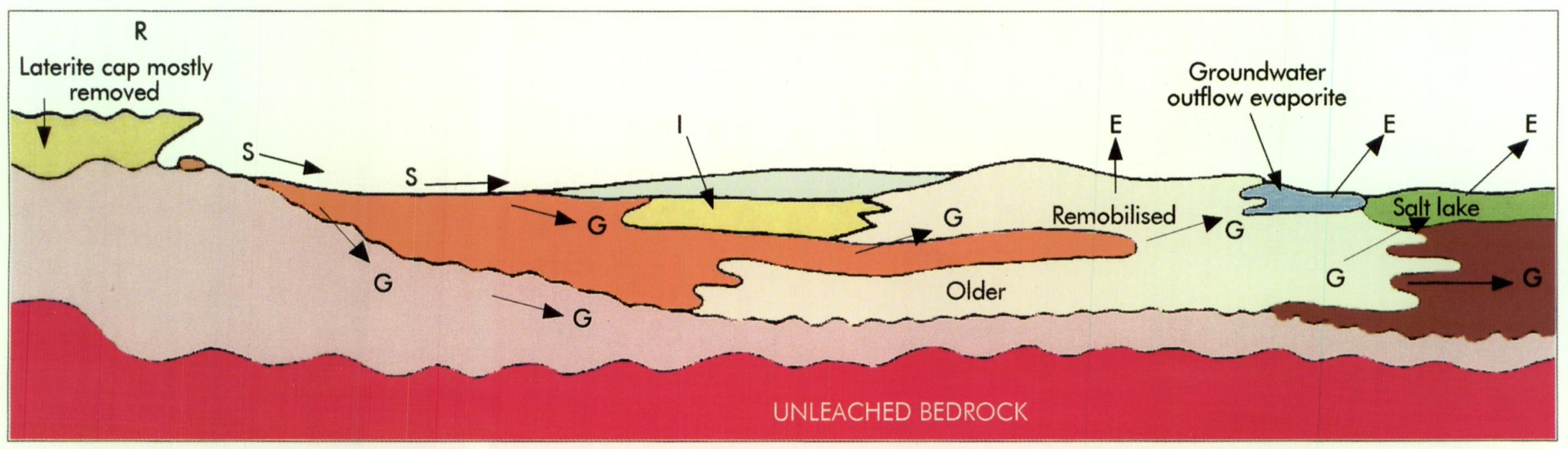

\begin{tabular}{|c|c|c|c|c|c|}
\hline & & & OXIDISING & & REDUCING \\
\hline & & BICARBONATE WATER & & $>$ CHLORIDE & SULPHATE WATER \\
\hline FRESH & $\begin{array}{l}\text { ALKALINE } \\
\mathrm{pm}\end{array}$ & & $\begin{array}{l}\text { SALINE ALKALINE } \\
5000-20000 \mathrm{ppm}\end{array}$ & & $\begin{array}{l}\text { HYPERSALINE NEUTRAL-ACID } \\
20000-200000(+) \mathrm{ppm}\end{array}$ \\
\hline $\begin{array}{l}\text { SOLUTION } \\
\text { CA MG HCO? FE }\end{array}$ & & $\begin{array}{l}\text { surface replacement of } \\
\text { Ca with } \mathrm{SiO}_{2}\end{array}$ & & Dolomite & \\
\hline MN FIXING $\mathrm{SIO}_{2}$ & $\mathrm{Fe} \mathrm{Mn}$ & $\begin{array}{l}\text { DEPOSITIO } \\
\text { carbonates rep }\end{array}$ & $\begin{array}{l}\text { VOF CALCRETE } \\
\text { lace iron hydroxide }\end{array}$ & & Colloidal clay evaporites \\
\hline
\end{tabular}

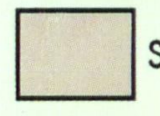

Saprolite and rock

Granite

\section{G - Groundwater flow}

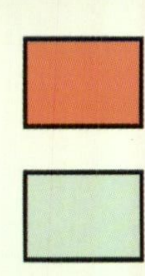

Leached ferruginous

sandstone fan and valley

fill. Abundant cemented aterine debris

Contemporary alluvial fan with ferricrete layer

\section{$R$ - Rainfall}

Opaline silica

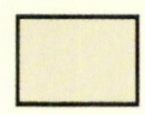

Calcrete

Contemporary salt pan clay

Trunk valley clay and sandy alluvium

I - Intake

E - Evaporation

Figure 5 Generalised longitudinal section of the northern part of the Raeside and Carey Palaeorivers showing dissected regolith to the north (left side) with a south facin erosion escarpment and accompanying pediment eroded into the saprolite layer. This feature is followed southwards (right side) by a sedimentary facies of ferricrete-cemented colluvial/alluvial fan, entering the palaeochannel sequence of calcrete, silica, lake basin clay, overlain by evaporites at the groundwater outflow at the salt lake. At the base are shown the changes to the physico-chemical conditions along the groundwater flowpath. This represents a single cycle of a series of hydrochemical cycles that occur along the length of the palaeochannel and which are associated with the saltlakes. Redrawn after Morgan (1993), with permission. 
downstream end of an individual hydrochemical system and immediately upstream of an evaporation outflow area forming a salt lake. This hydrochemical cycle may occur repeatedly along the length of a single palaeodrainage system (e.g., the Carey palaeodrainage system in Figure 1 in Watts and Humphreys, 1999, and Figure 40 in Watts and Humphreys 2000), giving rise to a string of salt lakes that are characteristic of the landscape of the Australian arid zone.

South of $29^{\circ} \mathrm{S}$, no such trend occurs in the hydrochemistry of the groundwater; little calcrete is deposited and the common ion ratio shows little alteration with increasing salinity. The groundwaters are typically acid, with sulphur reduction under anoxic conditions possibly associated with the carbonaceous deposits deep in the sediment channels.

The Morgan (1993) model of repeated hydrogeochemical cycles along the length of the palaeodrainage channel (Figure $2 a-c$ ), initiated by foci of major groundwater recharge, does not lead to easy prediction of the hierarchy of cladogenic events in the stygofauna restricted to the calcrete bodies. Resolution of the sequence of cladogenesis in conjunction with molecular clock estimates may contribute to our understanding of the evolution of these salt lake systems and the development of this arid-zone landscape.

\section{FAUNA}

Faunal assemblages, distribution and regional differences

The Western Shield is an area of large geographical extent (c. $10^{6} \mathrm{~km}^{2}$ ). Stygofaunal sampling, generally of low intensity, has been undertaken recently (since 1996) in the arid zone. The sampling sites are sparsely distributed but from widespread localities (Figure 6). In the context of a large scale faunal survey, some sites

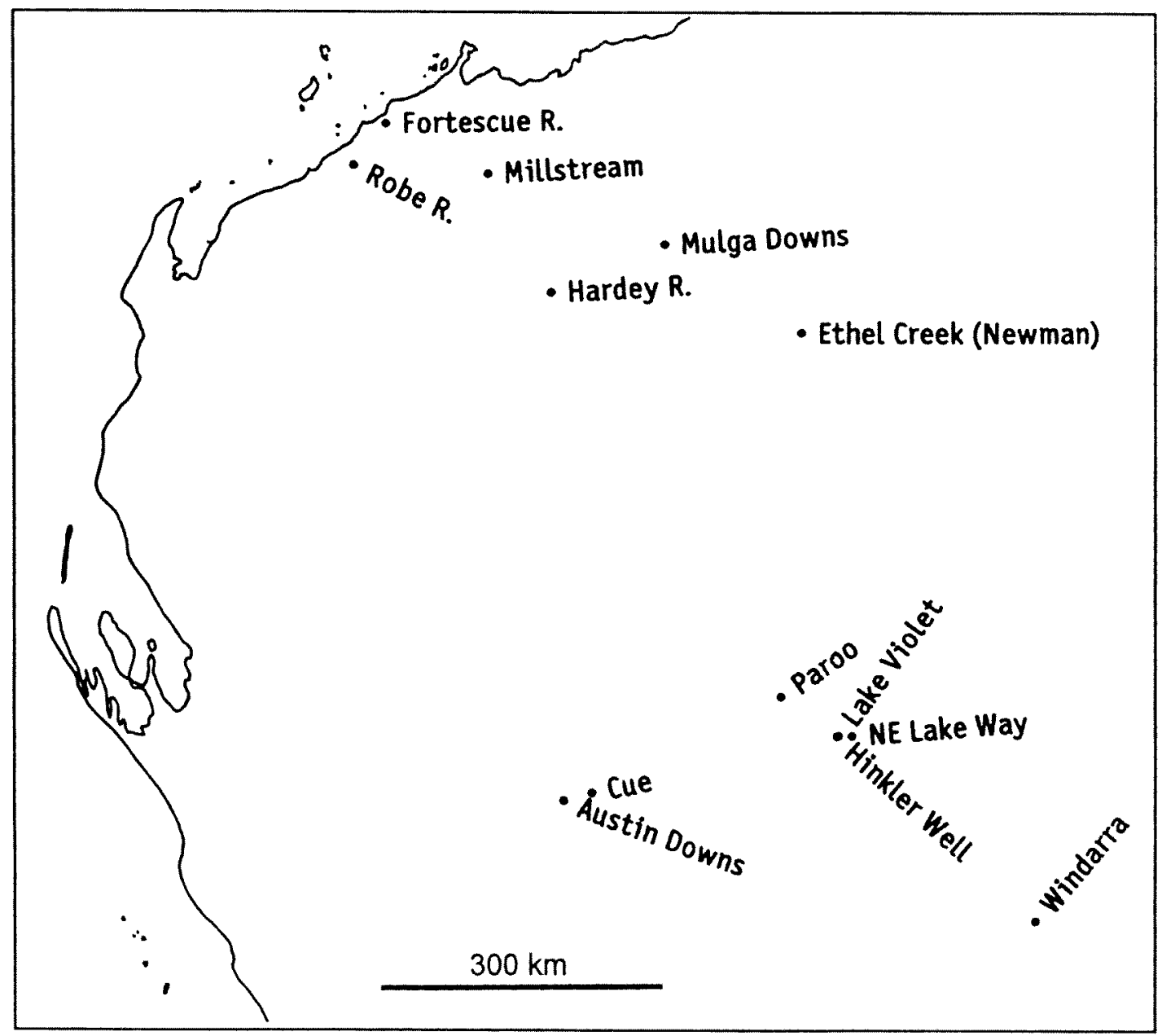

Figure 6 Fauna sampling sites and significant stygal aquifers on the Western Shield. Millstream is on the north central border of the Western Fortescue Plain. Ethel Creek is immediately to the east of Newman. The Hinkler Well label follows the approximate course of the Carey palaeodrainage between Paroo and Windarra. The separate Raeside palaeodrainage (between the labels for Austin Downs and Hinkler Well) has a separate fauna (June 2000), as do Roy Hill (north of Ethel Creek in the Fortescue Valley), and Savory and Ngarari Creek palaeochannels (south of Ethel Creek) that drain inland to Lake Disappointment (September 2000). 
have been adequately sampled (Western Fortescue Plain and Ethel Gorge) but others have received only passing attention (e.g. Mt Windarra, Cue).

Few of the taxonomic groups of stygofauna collected have been identified to species or genericlevel. Nonetheless, this process has allowed tentative recognition of local and regional differences in the composition and distribution of the stygal assemblages. Further, each discrete calcrete body examined thus far contains not only a unique stygal assemblage, but also comprises species apparently unique to that aquifer (Table 2).

In the following paragraphs, a synopsis of the stygal diversity of the Western Shield is given, together with the current state of taxonomic knowledge.
Pilbara

Stygofauna found initially on the Western Shield in the calcrete aquifers of the Western Fortescue Plain (the Millstream aquifer) had clear Gondwanan affinities (Harvey, 1998; Poore and Humphreys, 1998). This aquifer contains Spelaeogriphacea, an order previously only known from two caves in South Africa and Brazil (Poore and Humphreys, 1998). The associated stygofauna includes other taxa with Gondwanan affinities, such as Phreodrilidae (Oligochaeta: generally with a cool climate Gondwanan distribution: A. Pinder, personal communication 1997), Phreatoicidea (Pilbarophreatoicus Knott and Halse, 1999, Wilson and Johnson, 1999: Isopoda), crangonyctoid amphipods (gen. nov., J.H. Bradbury, personal communication 1999; Gondwanan Williams, 1986),

Table 2 Sundry taxa and their distribution on the 'Western Shield'.

\begin{tabular}{|c|c|c|}
\hline Area & Major taxon & Minor taxon \\
\hline \multicolumn{3}{|l|}{ Pilbara } \\
\hline $\begin{array}{l}\text { Fortescue Drainage } \\
\text { Ethel Gorge } \\
\text { Mulga Downs } \\
\text { Millstream } \\
\text { Ethel Gorge } \\
\text { Weeli Wolli } \\
\text { Mulga Downs } \\
\text { Millstream } \\
\text { Millstream } \\
\text { Ethel Gorge } \\
\text { Ethel Gorge } \\
\text { Weeli Wolli } \\
\text { Weeli Wolli } \\
\text { Coastal Plain } \\
\text { Coastal Plain + Millstream } \\
\text { Millstream } \\
\text { Millstream } \\
\text { Coastal Plain + Millstream } \\
\text { Coastal Plain + Robe }\end{array}$ & $\begin{array}{l}\text { Crangonyctoid amphipod } \\
\text { Crangonyctoid amphipod } \\
\text { Crangonyctoid amphipod } \\
{ }^{2} \\
{ }^{1} \text { Flabelliferan isopod } \\
{ }^{1} \text { Flabelliferan isopod } \\
\text { Ostracoda } \\
\text { Ostracoda } \\
\text { Ostracoda } \\
\text { Ostracoda } \\
\text { Ostracoda } \\
\text { Ostracoda } \\
\text { Ostracoda } \\
\text { Copepoda: Cyclopidae } \\
\text { Copepoda: Cyclopidae } \\
\text { Copepoda: Cyclopidae } \\
\text { Copepoda: Cyclopidae } \\
\text { Copepoda: Cyclopidae } \\
\text { Thermosbaenacea }\end{array}$ & $\begin{array}{l}\text { Gen. A sp. } 1 \text { to sp. } 14 \\
\text { Gen. A sp } 15 \\
\text { Gen. B. sp. } 1 \\
\text { Taxon A sp. } 1 \\
\text { Taxon A sp. } 2 \\
\text { Taxon B sp. } 3 \\
\text { Taxon B sp. } 2 \\
\text { Taxon B sp. } 1 \\
\text { Taxon C sp. } 1 \\
\text { Taxon C sp. } 2 \\
\text { Taxon C sp. } 3 \\
\text { Taxon C sp. } 4 \\
\text { Halicyclops rochai De Laurentiis et al. } \\
\text { Diacyclops humphreysi Pesce et al. } \\
\text { Diacyclops reidae De Laurentiis et al. } \\
\text { Diacyclops einslei De Laurentiis et al. } \\
\text { Mesocyclops brooksi Pesce et al. } \\
\text { Halosbaena tulki Poore \& Humphreys }\end{array}$ \\
\hline $\begin{array}{l}\text { Ashburton Drainage } \\
\text { Hardey River } \\
\text { Ashburton }\end{array}$ & $\begin{array}{l}\text { 'Flabelliferan isopod } \\
\text { Copepoda: Cyclopidae }\end{array}$ & $\begin{array}{l}\text { Taxon A sp. } 3 \\
\text { Mesocyclops brooksi Pesce et al. }\end{array}$ \\
\hline $\begin{array}{l}\text { Yigarn } \\
\text { Western drainage } \\
\text { Cue } \\
\text { Cue }\end{array}$ & $\begin{array}{l}\text { Isopoda: Oniscidea } \\
\text { Ostracoda }\end{array}$ & $\begin{array}{l}{ }^{4} \text { Haloniscus sp. } 1 \\
\text { Taxon D sp. } 1\end{array}$ \\
\hline $\begin{array}{l}\text { Eastern drainage } \\
\text { NE Lake Way } \\
\text { NE Lake Way } \\
\text { NE Lake Way } \\
\text { Paroo } \\
\text { Lake Violet }\end{array}$ & $\begin{array}{l}\text { Isopoda: Oniscidea } \\
\text { Isopoda: Oniscidea } \\
\text { Isopoda: Oniscidea } \\
\text { Ostracoda } \\
\text { Ostracoda }\end{array}$ & $\begin{array}{l}\text { Haloniscus sp. } 2 \\
\text { Haloniscus sp. } 3 \\
\text { Haloniscus sp. } 4 \\
\text { Taxon D sp. } 3 \\
\text { Taxon D sp. } 2\end{array}$ \\
\hline
\end{tabular}

1 Second clade of an undescribed family of flabelliferan isopod known elsewhere from the Kimberley (Wilson and Ponder, 1992); ${ }^{2}$ crangonyctoids belong to an ancient freshwater lineage (J.H. Bradbury, personal communication); Ceinidae (Amphipoda), a family of marine ancestry (Barnard and Karaman, 1984), are also present but have not been examined. ${ }^{3}$ See footote to Table 1. ${ }^{4}$ Haloniscus is elsewhere known from salt lakes in Australia (Bayly and Ellis, 1969; Williams, 1983) and anchialine systems in New Caledonia (Taiti et al., 1995). 
Table 3 Synopsis of the amphipod stygofauna of the northern Pilbara. The assessment was made by J.H. Bradbury from a broadscale screening of available material except that denoted that is in manuscript. A preliminary examination of further new material (101 specimens) from the Pilbara, predominantly in the Ashburton catchment, is estimated to contain an additional 15 species in 8 genera from three families, Paramelitidae, Melitidae and Bogidiellidae (J.H. Bradbury, personal communication, 20 February 2000).

\begin{tabular}{llll}
\hline & Genus & Species & Region \\
\hline A & Paramelitidae: & & \\
& New genus A & new species & Ethel Gorge borefield Bradbury 2000. \\
& & new species c & Fortescue Valley Bradbury submitted. \\
& new species d & Hardey River \\
& new genus B & new species a & Millstream Bradbury submitted. \\
B & Melitidae & Weeli Wolli \\
& Nedsia & new species a & Fortescue River bridge \\
& & new species b & Upper Ashburton \\
& & new species d & Millstream \\
C & New genus C & new species e & Millstream/Robe River aquifer \\
D & New genus D & new species a & Millstream \\
E & New genus E & new species a & Millstream \\
F & New genus F & new species a & Wiluna \\
\hline
\end{tabular}

and Tiramideopsis (Acari: genus previously known only from India: Harvey, 1998). Other stygofauna include a new hydrobiid (Gastropoda: W.F. Ponder, personal communication 1997), Bathynellacea (Syncarida), cyclopoid and harpacticoid Copepoda, Ostracoda ( $3+$ species), and ceinid and melitid amphipods. Several of these also probably have Pangaean affinities, including the Spelaeogriphacea (Poore and Humphreys, 1998), Syncarida (Schminke, 1974; Boutin and Coineau, 1987) and Crangonyctoidea (Barnard and Karaman, 1983).

This aquifer is isolated by a water gap downstream and a groundwater divide upstream (see Water gaps and groundwater divides), hence, the fauna is possibly confined to the western Fortescue plain (Poore and Humphreys, 1998). Downstream the stygofauna in the Robe River and Fortescue River alluvial aquifers on the coastal plain (Figure 6) is related to the Cape Range/Barrow Island anchialine fauna (Humphreys, 1999b, 2000a) having tethyan affinities (see Introduction). Upstream the fauna differs at the closest point sampled (upstream of the groundwater divide at Mulga Downs, the calcrete deposit second removed along the Fortescue River). At Ethel Gorge (Figures 6 and 7), a rich stygofauna occurs in calcrete (Eberhard and Humphreys, 1999) comprising numerous taxa of amphipods (Table 3 : Ceinidae and 14 species of a new genus of crangonyctoids not known from Millstream Bradbury, 2000) and a second clade (G.D.F. Wilson, personal communication 1998) of an undescribed family of flabelliferan isopods (Wilson and Ponder, 1992), a family known from throughout the Kimberley Devonian Reef system
(Humphreys, 1995; Limestone Billy Hills, W.F. Humphreys, unpublished; Ningbing Range, S.M. Eberhard, unpublished).

Other calcrete areas in the Pilbara that have been sampled for stygofauna, including the upper reaches of the next major drainage basin to the south, the Ashburton River, may be characterised by the presence of the flabelliferan isopod. This most distinctive stygal animal, uncharacteristically robust, clinging and opaque, is represented by a different taxon at all sites so far investigated in the Pilbara (G.D.F. Wilson, personal communication 1998). In addition, all sites contain diverse amphipods, ostracods (especially Candoninae), and copepods (especially Cyclopoidea).

Thus the Pilbara appears to have three types of stygal assemblages distributed in discrete regions:

1, the coastal plain comprising the alluvial fan aquifers of the lower Robe and Fortescue Rivers which has a tethyan community characterised by Stygiocaris (Atyidae), Haptolana (Cirolanidae) and Halosbaena (Thermosbaenacea), of which the latter intrude to an altitude of $300 \mathrm{~m}$ on the Robe River, the approximate level of the Late Eocene sealevel high on the Yilgarn (G.W. Kendrick, personal communication, 1999),

2, the Western Fortescue Plain characterised by Spelaeogriphacea and the associated fauna with Gondwanan affinities, and

3. sites upstream of the Western Fortescue Plain and the upper Ashburton catchment characterised by flabelliferan isopods.

Each of these assemblages also has an array of Amphipoda, Ostracoda, Copepoda, Syncarida (Bathynellacea) and Oligochaeta (Phreodrilidae) 
Table 4 The distribution of stygal species of dytiscids amongst discrete calcrete bodies in the Yilgarn district of Western Australia. From Watts and Humphreys $\left(1999^{1}, 2000\right)$. Superscripts between $2-4$ in common denote sympatric species. A new genus and five new species of stygal Dytiscidae were collected (June 2000) in the separate easterly trending Raeside palaeodrainage (see caption Figure 6) and one new species from a separate calcrete in the Austin palaeodrainage (Watts and Humphreys, unpublished). Thus, 18 stygal dytiscid species occur in the Yilgarn compared with the world total recorded by Spangler and Decu (1999) of 17 species in 12 ( 9 monotypic) genera.

\begin{tabular}{|c|c|c|c|}
\hline $\begin{array}{l}\text { Genus } \\
\text { Calcrete body }\end{array}$ & Tjirtudessus W \& $\mathbf{H}^{1}$ & Nirridessus W \& $\mathbf{H}$ & Kintingka W \& $\mathrm{H}$ \\
\hline \multicolumn{4}{|c|}{ Western drainage } \\
\hline Austin Downs & - & bigbellensis & - \\
\hline Cue & magnificus ${ }^{4}$ & cueensis $^{4}$ & - \\
\hline \multicolumn{4}{|c|}{ Eastern drainage } \\
\hline Paroo & eberhardi ${ }^{2}$ & pulpa ${ }^{2}$ & kurutjutu ${ }^{2}$ \\
\hline Lake Violet & - & undescribed sp. & - \\
\hline NE Lake Way & hahni & morgani & - \\
\hline Hinkler Well & - & hinkleri & - \\
\hline Windarra & - & windarraensis ${ }^{3}$ & - \\
\hline- & - & lapostaae $e^{3}$ & - \\
\hline
\end{tabular}

which have mostly yet to be taxonomically worked in any detail.

\section{Yilgarn}

Stygal assemblages inhabiting groundwater calcretes in the Murchison district of the Yilgarn (Figure 6) are distinguished by the presence of diving beetles (Coleoptera: Dytiscidae), with up to three genera occurring sympatrically (Table 4). Different species of dytiscid are found in each separate calcrete body examined to date (Watts and Humphreys, 1999, 2000). Congeneric species of the dytiscids are found on either side of the drainage divide that separates the drainage to the Indian Ocean from that draining to the interior of the continent. Because groundwater connections across this ancient water divide on Precambrian rocks are unlikely, the beetles may have evolved from a widespread epigean ancestor. The dytiscids are associated with a diversity of Bathynellacea, Amphipoda (Crangonyctoidea and Ceinidae: J.H. Bradbury, personal communication, 1999), Ostracoda, Copepoda (Harpacticoidea and Cyclopoidea), Oligochaeta (Phreodrilidae: A. Pinder, personal communication, 1999) and Isopoda: Oniscidea (Haloniscus spp.: S. Taiti, personal communication, 1999).

\section{AQUIFER CHARACTERISTICS}

\section{Water quality and stratification}

The characteristics and quality of groundwater flowing alongside (parafluvial) and beneath (hyporheic) surface waters change with distance from the groundwater/surface water ecotone and with the relative water pressure which determine whether the water is flowing into or out of the groundwater system. These interactions and properties influence both the river fauna (Boulton, 1993,2001 ) and the interstitial and stygofauna along the course of a river (Danielopol et al., 2000; DoleOlivier et al., 1994; Ward et al., 2000).

In the Australian arid zone, large spatial and temporal changes in water quality occur that result from the hydrogeochemical processes in the groundwater flow (see Morgan's model above). The unpredictable and highly episodic rainfall, characteristic of the arid zone (Sanders, 1973), recharges calcrete aquifers through porous, often karstic surfaces (Barnett and Commander, 1985; Arakel et al., 1990). These large but episodic recharge events may cause the groundwater table to fluctuate widely in height Jacobson and Arakel, 1986; Morgan, 1993), accompanied by large changes in salinity, especially near the groundwater surface (Morgan, 1993; Watts and Humphreys, 1999). Quite subtle changes, such as to the height of the water table, or in the direction of groundwater flow, may have profound effects on the location of stygal populations.

Stygofauna occurs in calcretes where the groundwater surface is only $2 \mathrm{~m}$ below the surface (Windarra), and up to $27 \mathrm{~m}$ below the surface in the Western Fortescue Plain where the calcrete aquifer itself is up to $30 \mathrm{~m}$ thick (Barnett and Commander, 1985). Elsewhere in Australia stygofauna is known from water tables $59 \mathrm{~m}$ below the surface and in water up to $33 \mathrm{~m}$ deep. For comparison, the artesian Edwards Aquifer in Texas, USA, supports a diverse stygofauna $415-615 \mathrm{~m}$ below the surface in an artesian system (Longley, 1992), while amphipods and molluscs, inter alia, occur from one kilometre depth in Morocco (Essafi et al., 1998).

Fresh to saline groundwaters occur widely in calcretes of the palaeodrainage channels of the Western Shield and often, perhaps typically, have 
fresher water overlying saline deeper water. Such salinity stratified systems may be damaged by the underlying saline layers intruding into the overlying fresh water as a result of excessive pumping. The stygofauna from the Pilbara has been found in fresh waters (salinity $<1 \mathrm{~g} \mathrm{~L}^{-1} \mathrm{TDS}$ ) but in the Yilgarn, stygofauna has been found widely in waters of salinity $1-5 \mathrm{~g} \mathrm{~L}^{-1}$ TDS. Northeast of Lake Way, stygofauna occurs in waters with a salinity stratified from 23 to $41 \mathrm{~g} \mathrm{~L}^{-1}$ (Figure 39 in Watts and Humphreys, 2000) but the salinity zone occupied by the fauna is unknown. This record may be the first stygofauna known from highly saline midcontinental waters.

Williams et al. (1990) sampled invertebrates from 79 salt lakes in western Victoria, Australia. Twentynine percent of the 142 species examined were found in waters with salinity greater than $23 \mathrm{~g} \mathrm{~L}^{-1}$. Higher taxa were differentially represented in water with salinity greater than $23 \mathrm{~g} \mathrm{~L}^{-1}$, ranging from total absence of species (Hydracarina, Odonata, Lepidoptera, Trichoptera), from $20-40 \%$ of species (Hemiptera, Mollusca, Ostracoda), to more than $40 \%$ of species (Malacostraca, Copepoda, Diptera); only $12 \%$ of Coleoptera species were found in these high salinity waters. Species richness from saline lakes ( 3 to $100 \mathrm{~g} \mathrm{~L}^{-1}$ ) was not markedly lower than that of freshwater lakes, and they concluded that salinity may not be an important determinant of species occurrence over most of the salinity range occupied by the fauna of salt lakes.

These findings (Williams et al., 1990) are of particular interest in the context of the calcrete aquifers which may exhibit strong salinity stratification (Figure 39 in Watts and Humphreys, 2000 ) or fluctuate markedly in salinity at the surface (e.g. annual range between 5-22 $\mathrm{g} \mathrm{L}^{-1}$ : footnote Table 2 in Watts and Humphreys, 2000). Thus, not only is a wide range of salinity tolerant species available to colonise stygal habitats in Australia, but, once adapted to subterranean life, the particular salinity, over a wide range, may not be a prime determinant of their occurrence.

Such strong salinity gradients in groundwater are often associated with ecotones, as found, for example, in anchialine waters in Mexico (Pohlman et al., 1997, 2000) and on the Cape Range peninsula of Western Australia (Humphreys, 1999a). In the latter, a complex physico-chemical stratification occurred associated with the halocline in which the salinity changed from 19 to $32 \mathrm{~g} \mathrm{~L}^{-1}$ through a depth change of $8.5 \mathrm{~m}$. A diverse microbial assemblage was associated with the resulting oxic/anoxic boundary and, not surprisingly, the stygofauna varied with depth within this system (Humphreys, 1999a), as found elsewhere (Sket, 1986). An analogous chemoautotrophic system may occur associated with the marked salinity stratification found in calcretes of the Western Shield. The plausibility of such a mechanism in the calcretes is enhanced because groundwaters in desert regions typically have high nitrate and sulphate contents (K.H. Morgan, personal communication, 1999) which, under reducing conditions, could support chemoautotrophic sulphur bacteria (Schulz et al., 1999). In addition, this ecosystem and its fauna may segregate around the halocline, as found in anchialine ecosystems (Sket, 1986; Humphreys, 1999a).

\section{Limits in time and space}

An absence of sediment (unconformity) between the Permian and Eocene, throughout the Yilgarn and Pilbara cratons and in much of the intervening Proterozoic basins (L. Worrall, CRCAMET, CSIRO, personal communication, 1998), largely constrains the distribution and timing of colonisation and vicariant events of fauna confined to groundwaters; it could also have disrupted the hyporheic corridor.

The Wittenoom Dolomite, of Proterozoic age, is widespread in the Pilbara. Its upper parts are often karstic and in contact with Tertiary deposits (Barnett and Commander, 1985). This formation may have provided a long term refuge for stygofauna throughout the Mesozoic and account for the presence of an apparently much older fauna in Tertiary aquifers (Poore and Humphreys, 1998; Humphreys, 1999b). This process has also been argued for other taxa in different formations at other localities (Humphreys, 1993, 2000b, 2000c).

Such profound geomorphological constraints are likely to have had a large influence on the composition and distribution of stygofaunal assemblages. The constraints imposed by the erosional landscape on existent and putative stygofauna throughout the Mesozoic may have been released with the onset of a depositional environment in the palaeochannels during the Tertiary.

Although the stygofauna of the Western Shield differs regionally, as well as between the various calcrete bodies within a region, from first principles the stygofauna may be expected to occur widely within a given calcrete body. This is because karst development is widespread near the water table in such aquifers and the resulting open conduit flow should permit wide dissemination of any contained stygofauna. However, no evidence supports this contention of widespread distribution of stygal species within a given calcrete aquifer. Two examples can be given:

During the initial examination of the Western Shield aquifers in 1996, a total of 46 bores was sampled in the central regions of the Western Fortescue Plain aquifer (Millstream). Spelaeogriphaceans were collected from eight of the sites. The following year 24 additional bores were sampled (plus 20 of the original bores) and together these samples encompassed almost the entire aquifer, 


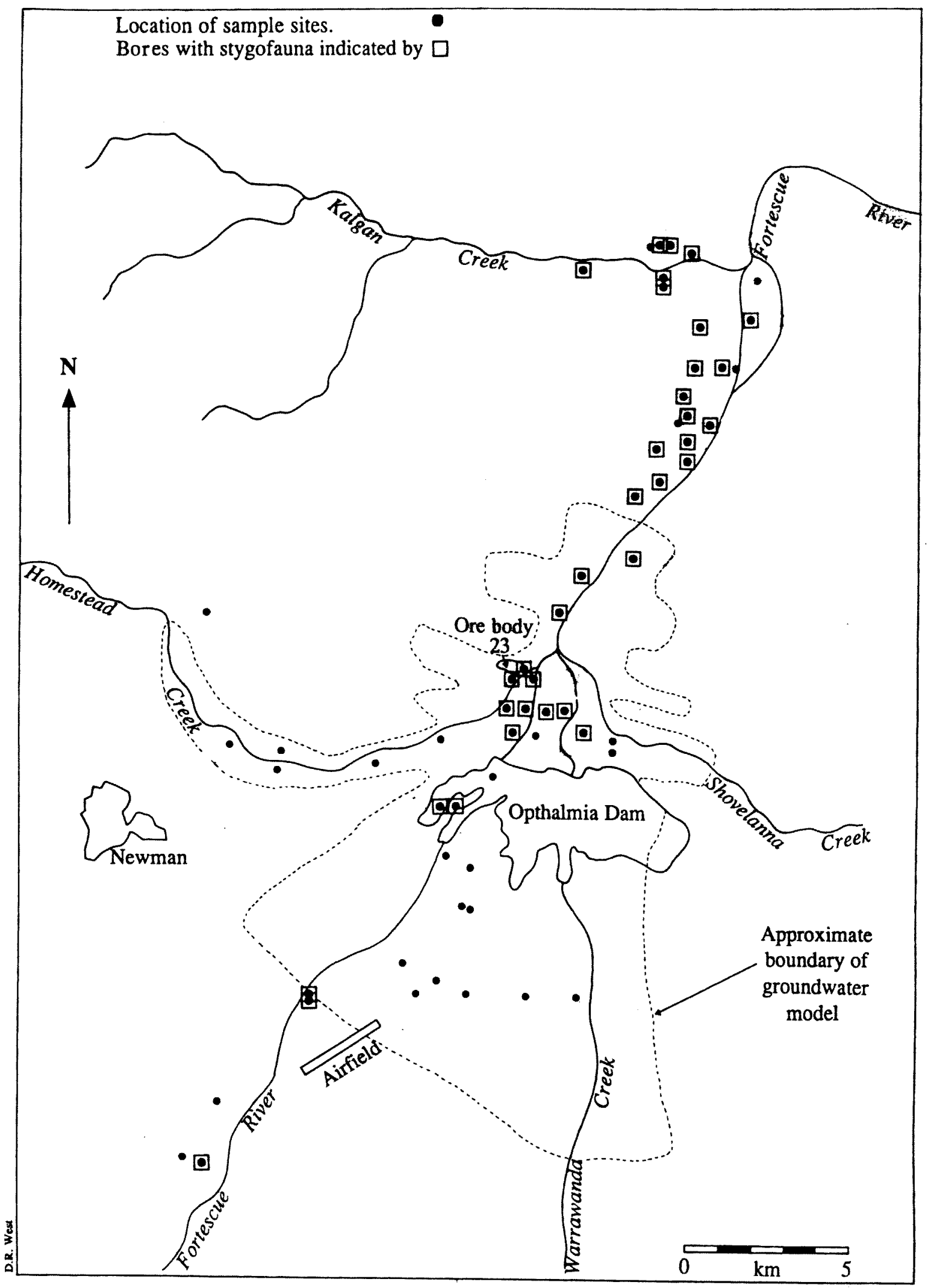

Figure 7 Calcrete aquifer at the junction of the Fortescue River with Homestead, Warrawanda and Shovelanna Creeks near Ethel Gorge, Upper Fortescue. The dotted line represents the limits to the drawdown model (BHP, 1997) for a proposed mining operation involving dewatering below the calcrete (after Eberhard and Humphreys, 1999). This is the most specious stygal amphipod site known globally, containing 14 Chydeakata (Bradbury) species (Paramelitidae), largely known only from the central area of the proposed drawdown. The next most specious sites, though taxonomically more diverse, are Barrow Island, W.A. (3, 3, 12 family, general, species minimum), Edwards Aquifer, Texas (4, 7, 10; J.R. Holsinger, personal communication, 2000), Pecina Vjetrenica (Dinaric karst, 3, 3, 10) and Sava River at Dovjez, Slovenia: interstitial, 2, 2, 9; B. Sket, personal cummunication, 2000). 
including both sides of the groundwater divide between the Robe and Fortescue drainages. No additional sites produced spelaeogriphaceans (Figure 8; Poore and Humphreys, 1998). Furthermore, some taxa collected from the Millstream aquifer in 1996 were not collected again in 1997, either at the same sites or elsewhere, suggesting that some taxa may be sparse, even rare (e.g. the Phreodrilidae), while others seem to be restricted to discharge areas (e.g. Phreatoicidea). The failure of additional sampling to locate more spelaeogriphacean sites on the Western Fortescue Plain (Poore and Humphreys, 1998) suggests that a given calcrete body cannot be considered as an homogeneous stygal habitat.

In this context, bores may produce artefacts that change the apparent density, composition and distribution of the stygofauna by:

1. acting as conduits for organic carbon from the surface thus providing a superabundance of food energy to an otherwise typically low energy system; depending on the amount, this additional energy may be expected either to attract, thus concentrate the stygofauna in the bore, or else permit epigean taxa to displace stygofauna (Malard, 1995). In this respect handdug wells of large diameter (1-3 m) often do not contain stygofauna while adjacent narrow bore wells (bores) commonly do.

2, providing sampling access though water physico-chemically stratified thereby mixing the natural vertically separated faunas;

3, permit faunas from normally unconnected aquifers at different depths to mix;

4, providing an artificial substrate and gaseous exchange interface (changing the redox profile) permitting otherwise separated communities to coexist; and

5, introducing iron (steel pipes) as substrate on which iron bacteria could act (see Fenchel and Finlay, 1995).

The calcrete and neighbouring alluvial and fractured rock aquifers associated with the confluence of several creeks at Ethel Gorge calcrete on the upper Fortescue were sampled for stygofauna at 79 locations (Eberhard and Humphreys, 1999). Stygofauna was recovered from 43 bores and included bathynellids, phreatoicidean and flabelliferan isopods, amphipods, copepods and ostracods. Just one family (crangonytoid amphipods) has been examined taxonomically in detail from the Ethel Gorge calcrete. Despite the widespread sampling in the area, most species of amphipod (10 of 13 undescribed species) are known from only a very small part $(<4 \%)$ of this calcrete (Figure 7), in an area planned to be dewatered to a projected depth of $140 \mathrm{~m}$ below the surface for a short term mining operation (BHP, 1997). This calcrete aquifer was repeatedly drawn-down to a moderate extent at Ethel Gorge in the 1970s (G.B. Clark, personal communication, 1999), possibly sufficient to affect phreatophytic vegetation.

\section{DISCUSSION}

In recent years stygofauna, groundwater and aquifer ecosystems, have become the focus of much attention on account of the biodiversity and functions therein (Botosaneanu, 1986; Gibert et al., 1994; Juberthie and Decu, 1994, 1998; Culver et al., 1995; Wilkens et al., 2000). There is an increasing realisation that they represent a major component of biodiversity, sometimes greater than the diversity in surface waters (Rouch and Danielopol, 1997), and that they comprise complex ecosystems interacting with surface systems in a manner pertinent both to groundwater and surface water quality (Gibert et al., 1994). Recently the major part of an entire issue of an international journal was devoted to the biodiversity of Crustacea in subterranean waters [Crustaceana 72(8) (1999)].

Much work is needed to start to understand the distribution and distinctiveness of the stygofauna of the groundwater calcrete aquifers of the Western Shield. The initial hypothesis proposed for the development of fresh groundwater refugia at the head of the tributaries of the palaeodrainage systems (section Potential isolating factors) at this stage seems too simplistic, and the development is at least more complex and perhaps fundamentally different from that proposed. The presence of distinct faunas in each calcrete area is consistent with the evolution of the hydrogeological system in the palaeodrainage channels (Mann and Deutscher, 1978) as interpreted by Morgan (1993). Namely, the hydrogeological cycles repeated along the length of the palaeodrainage line. The age and stability of the palaeodrainage systems and the suitability for stygofauna of calcrete aquifers, coupled with the repeated cycles of fresh to hypersaline $\left(>200 \mathrm{~g} \mathrm{~L}^{-1}\right)$ groundwaters along the length of each palaeodrainage system would effectively isolate each stygal assemblage within the region where groundwater characteristics are suitable for their development. Of species found in salt lakes $97 \%$ were excluded in such hypersaline waters (Williams et al., 1990).

\section{Conservation}

Groundwater calcretes are a major source of potable, stock and industrial water in the arid zone. Furthermore, calcretes are used extensively as a limestone resource, predominantly for neutralising acids resulting from mining operations or mineral processing, and for construction. While the impact of a well managed water abstraction borefield on stygofauna is unknown, a poorly managed system 

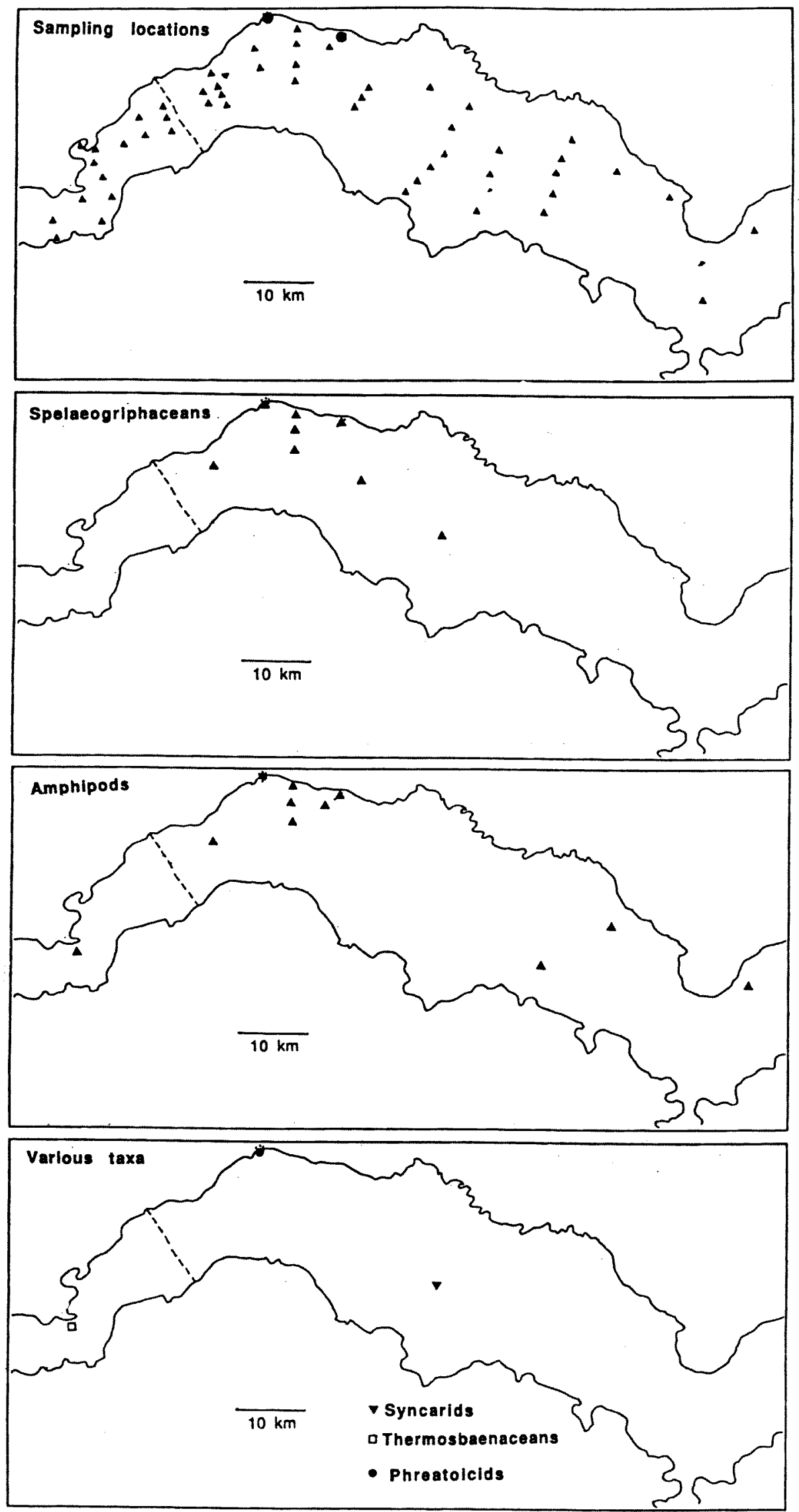

Figure 8 Western Fortescue Plain aquifer (based on Barnett and Commander, 1985) showing sampling locations (triangles in upper map: circles denote multiple sampling points at Palm Springs and Millstream), and the distribution of selected stygofauna taxa in the aquifer of the Western Fortescue Plain. The groundwater divide between the Fortescue and Robe River drainages is denoted by a broken line. 
may result in the upward intrusion of salt water within the aquifer. The quarrying of calcretes may remove habitat for stygofauna and expose the water table to greater evaporation, thereby foreshortening the temporal and physical development of the typical groundwater flow envisaged in Morgans model. While the effect of these impacts is uncertain, even quite subtle changes in groundwater quality and quantity, as well as their temporal expression, may have profound effects on the location of stygal populations, for example in the Dytiscidae (Richoux and Reygrobellet, 1986). Unique stygal assemblages may be lost if groundwater pollution occurs (Uéno, 1996).

These ecosystems may face significant risks resulting from the lowering of the water table below ecologically appropriate levels as a result of surface operations (sealing or clearing), as well as those below ground (water abstraction, mine dewatering). In addition, such processes may result in the physical modification or loss of subterranean environments through general surface slumping in floodplain calcrete aquifers resulting from the withdrawal of supporting water.

The discovery that groundwater calcrete aquifers in the Australian arid zone contain rich relictual faunas (Poore and Humphreys, 1998; Humphreys, 1999b; Watts and Humphreys, 1999, 2000), and that these faunas differ between even closely adjacent sites, poses challenging management issues for both operators and regulators.

Hatton and Evans (1998) review of groundwater dependent ecosystems recognised the groundwater dependence of aquifer ecosystems and that it is to be expected these ecosystems represent a key part of the food chain and ecological processes which emerge as river base flow and flow into wetlands. However, they failed to appreciate the diversity of Australia's subterranean fauna, the amount of the information available, or the range in types and extent of aquifer ecosystems present in Australia. As a consequence, they severely underestimated (at $1 \%$ ) the proportion of Australia covered by groundwater dependent ecosystems, especially those arid zone aquifers within groundwater calcretes. While the authors have subsequently recognized this (T. Hatton and R. Evans, in litt. 1999), the timing was unfortunate as it coincided with policy development by the States and Territories on groundwater dependent ecosystems.

\section{Conclusions}

Of the hypotheses suggested earlier:

1) Other arid regions do contain relictual stygofauna.

2) The stygofauna includes ancient freshwater lineages (Syncarida, Crangonyctoidea), probably more recent ones (Dytiscidae), and some ambivalent (Oniscidea).
3) Headwater aquifers do contain distinct but related faunas (Paroo, Hinkler Well: Table 4, Figure 6). In addition, however, non-headwater aquifers - those in line along a given palaeodrainage channel - also contain distinct but related faunas (Paroo, Lake Violet, Windarra: Table 4, Figure 6).

4) Calcrete aquifers do each contain separate faunas comprising significant biodiversity.

5) The Gondwanan affinities of much of the stygofauna of the Western Fortescue Plain suggests an earlier origin than the lacustrine calcrete of Tertiary age in which the fauna occurs; as it is karstic in places the underlying Wittenoom Dolomite, of Proterozoic age, is a prime candidate, although no stygofauna has definitively been recovered from it to date.

The fauna of the calcrete aquifers of the Australian arid zone has barely been examined. Already, some taxonomic groups of the stygofauna comprise the most diverse of any in the world. As with other ecosystems, these complex aquifer ecosystems - of which only the macroinvertebrate section is discussed in this paper - may be expected to provide 'ecosystem services', the nature and extent of which we are largely ignorant. It is to maintain these ecosystem functions that is the thrust of biodiversity debate. In this state of blissful ignorance these ecosystems are being impacted by human activities at an increasing rate. Notwithstanding, these aquifer ecosystems offer exciting opportunities for research into the evolution of subterranean lineages, as well as on the progressive impact of aridity in Australia. The presence of such highly diverse and locally endemic stygofauna, often ancient relictual lineages, in a major economic resource within arid Australia poses delicate and challenging conservation issues. At the same time the scientific challenge is considerable to understand the development and functioning of these systems in order that they can be managed sustainably.

\section{ACKNOWLEDGEMENTS}

I thank the numerous hydrogeologists and environmental officers within parts of the mining industry, consultants, pastoralists and officers of government agencies who have facilitated access to information on calcrete aquifers and to sampling sites on the Western Shield. They are acknowledged personally in more specific papers.

Preliminary information on various taxa was provided by J.H. Bradbury (Amphipoda), A. Pinder (Oligochaeta), P. Marmonier (Ostracoda), G. Pesce (Copepoda), H. K. Schminke (Bathynellacea), G. D. F. Wilson and S. Taiti (Isopoda). I thank H.J. Hahn (Universität Koblenz-Landau, Germany), S.M. Eberhard (Caveworks, Western Australia) and J. 
Waldock (W.A. Museum) for their stimulating assistance both in the field and laboratory. This work was facilitated by funding from the Western Australian Museum, the Water Corporation of Western Australia, Mr and Mrs W.H. Butler, BHP Iron Ore Pty. Ltd., Anaconda Nickel Pty Ltd., and the Visa Card Trust Fund administered by the Department of Conservation and Land Management. I thank Andrew Boulton and Buz Wilson whose perceptive and constructive comments at the refereeing stage did much to improve this paper.

\section{REFERENCES}

Arakel, A.V. (1996). Quaternary vadose calcretes revisited. Journal of Australian Geology and Geophysics 16: 223-229.

Arakel, A.V., Jacobson, G. and Lyons, W.B. (1990). Sediment water interaction as a control on geochemical evolution of playa lake systems in the Australian arid interior. Hydrobiologia 197:1-12.

Barnard, J.L. and Karaman, G.S. (1983). The higher classification of amphipods. Crustaceana 28: 304-310.

Barnard, L.J. and Karaman, G.S. (1984). Australia as a major evolutionary centre for Amphipoda (Crustacea). Memoirs of the Australian Museum 18: 4561.

Barnett, J.C., and Commander, D. P. (1985). Hydrogeology of the western Fortescue Valley, Pilbara Region, Western Australia. Geological Survey Record 1986/8. Western Australia Geological Survey, Perth.

Bayly, I.A.E. and Ellis, P. (1969). Haloniscus searlei Chilton: an aquatic "terrestrial" isopod with remarkable powers of osmotic regulation. Comparative Biochemistry and Physiology 31: 523-528.

Beard, J.S. (1998). Position and development history of the central watershed of the Western Shield, Western Australia. Journal of the Royal Society of Western Australia 81: 157-164.

BHP (1997). Newman satellite development - Mining of Orebody 23 below the watertable. Consultative Environmental Review. Prepared for BHP by Woodward-Clyde. BHP Iron Ore Pty. Ltd., Perth.

BMR Palaeogeographic Group. (1990). Australia, evolution of a continent. Australian Government Publishing Service, Canberra.

Botosaneanu, L. (ed.), 1986. Stygofauna Mundi: A faunistic, distributional, and ecological synthesis of the world fauna inhabiting subterranean waters. (including the marine interstitial). E.J. Brill, Leiden.

Boulton, A.J. (1993). Stream ecology and surfacehyporheic hydrologic exchange: implications, techniques and limitations. Australian Journal of Marine and Freshwater Research 44: 553-564.

Boulton, A.J. (2001). 'Twixt two worlds: taxonomic and functional biodiversity at the surface water/ groundwater interface. Records of the Western Australian Museum, Supplement No. 64: 1-13.

Boutin, C. (1993). Biogéographie historique des crustacés malacostracés stygobies du Maroc. Thesis: L'Université Claude Bernard-Lyon I.

Boutin, C. and Coineau, N. (1987). Iberobathynella (Crustacea, Syncarida, Bathynellacea) sur le continent africain. Implications paléobiogéographiques. Comptes Rendus Acadamies de Sciences, Paris 304 (Sér. III) (13): 355-357.

Boutin, C. and Coineau, N. (1990). "Regression Model", "Modèle Biphase" d'évolution et origine des microorganismes stygobies interstitiels continentaux. Revue de Micropaléontologie 33: 303-322.

Bowler, J.M. (1976). Aridity in Australia: age, origins and expression in aeolian landforms and sediments. Earth Science Reviews 12: 279-310.

Bradbury, J. H. (2000). Western Australian stygobiont amphipods (Crustacea: Paramelitidae) from the Mt Newman and Millstream regions. Records of the Western Australian Museum Supplement No. 60: 1-102.

Bradbury, J.H., and Eberhard, S.M. (2000). A new stygobiont melitid amphipod from the Nullarbor Plain. Records of the Western Australian Museum 20: 5566.

Bradbury, J.H., and Williams, W.D. (1996a). Freshwater amphipods from Barrow Island, Western Australia. Records of the Australian Museum 48: 33-74.

Bradbury, J.H., and Williams, W.D. (1996b). Two new species of anchialine amphipod (Crustacea: Hadziidae: Liagoceradocus) from Western Australia. Records of the Western Australian Museum 17: 395-409.

Bradbury, J.H. and Williams, W.D. (1997a). Amphipod (Crustacea) diversity in underground waters in Australia: an Aladdin's Cave. Memoirs of the Museum of Victoria 56: 513-519.

Bradbury, J.H. and Williams, W.D. (1997b). The amphipod (Crustacea) stygofauna of Australia: description of new taxa (Melitidae, Neoniphargidae, Paramelitidae), and a synopsis of known species. Records of the Australian Museum 49: 249-341.

Brunke, M. and Gonser, T. (1997). The ecological significance of exchange processes between rivers and groundwater. Freshwater Biology 37: 1-33.

Butt, C.R.M., Horwitz, R.C. and Mann, A.W. (1977). Uranium occurrence in calcrete and associated sediments in Western Australia. Australia, CSIRO Division of Mineralogy, Mineral Research Laboratories Report FP16.

Carroll, D. (1947). Heavy residues of soils from the Lower Ord Valley, Western Australia. Journal of Sedimentary Petrology 17: 8-17.

Commander, D.P. (1994a). Hydrogeology of the Robe River alluvium, Ashburton Plain, Carnarvon Basin. Geological Survey of Western Australia: Professional Papers, Report 37: 75-100.

Commander, D.P. (1994b). Hydrogeology of the Fortescue River alluvium, Ashburton Plain, Carnarvon Basin. Geological Survey of Western Australia: Professional Papers, Report 37: 101-124.

Culver, D.C., Kane, T.C. and Fong, D.W. (1995). Adaptation and natural selection in caves: the evolution of Gammarus minus. Harvard University Press, Cambridge, Massachusetts.

Danielopol, D.L., Baltanás, A. and Humphreys, W.F. 
(2000). Danielopolina kornickeri sp. n. (Ostracoda: Thaumatocypridoidea) from a western Australian anchialine cave - morphology and evolution. Zoologica Scripta 29: 1-16.

Danielopol, D.L. , Pospisil, P., and Dreher, J. (2000). Danube wetland groundwater system. In $\mathrm{H}$. Wilkens, D.C. Culver and W.F. Humphreys (eds). Ecosystems of the world, vol. 30. Subterranean ecosystems. Elsevier, Amsterdam: 481-511.

De Laurentiis, P., Pesce, G.L. and Humphreys, W.F. (1999). Copepods from ground waters of Western Australia, IV. Cyclopids from basin and craton aquifers (Crustacea: Copepoda: Cyclopidae). Records of the Western Australian Museum 19: 243-257.

Dole-Olivier, M.-J., Marmonier, P., Creuzé des Châtelliers, M. and Martin, D. (1994). Interstitial fauna associated with the floodplains of the Rhône River (France). In J. Gibert, D.L. Danielopol and J.A. Stanford (eds). Groundwater Ecology: 313-346. Academic Press, London.

Eberhard, S.M., Richardson, A.M. and Swain, R. (1991). The invertebrate cave fauna of Tasmania. Unpublished Report to the National Estate Office, Canberra. 107 pp.

Eberhard, S.M. and Spate, A. (1995). Cave invertebrate survey: toward an atlas of New South Wales cave fauna. Unpublished Report prepared under the NSW Heritage Assistance Program. 112 pp.

Eberhard, S.M. and Humphreys, W.F. (1999). Stygofauna survey - Ore Body 23 (Newman) and Mine Area C. A report prepared for BHP Iron Ore Pty. Ltd. 59 pp.

EPA (1981). Lake Way uranium proposal by Delhi International Oil Corp and VAM Ltd Joint VentureReport and recommendations by the Environmental Protection Authority, Western Australia. Department of Conservation and Environment, Bulletin 106, 46p.

Essafi, K., Mathieu, J., Berrady, I. and Chergui, H. (1998). Qualite de l'eau et de la faune au niveau de forages artesiens dans la Plaine de Fes et la Plaine des BeniSadden. Premiers resultats. Mémoires de Biospéologie 25: 157-166.

Fenchel, T. and Finlay, B. J. (1995). Ecology and evolution in anoxic worlds. Oxford University Press, Oxford.

Geological Survey. (1989). Hydrogeological map of Western Australia, 1: 2,500,000. Geological Survey of Western Australia, Perth.

Geological Survey. (1990). Geology and mineral resources of Western Australia. Western Australia Geological Survey, Memoir No. 3: 1-827 (plus map volume).

Gibert, J., Danielopol, D.L. and Stanford, J.A. (eds). (1994). Groundwater Ecology. Academic Press, London.

Gibert, J., Fournier, F. and Mathieu, J. (1997). The groundwater/ surfacewater ecotone perspective: state of the art. In J. Gibert, J. Mathieu and F. Fournier (eds). Groundwater/surface water ecotones: biological and hydrological interactions and management options. Cambridge University Press, Cambridge: 3-8.

Harvey, M.S. (1998). Unusual new water mites (Acari: Hydracarina) from Australia, Part 1. Records of the Western Australian Museum 19: 91-106.

Hatton, T. and Evans, R. (1998). Dependence of Ecosystems on Groundwater and its Significance to Australia. Land and Water Resources Research and Development Corporation Occasional Paper 12/98.

Holsinger, J.R. (1994). Pattern and process in the biogeography of subterranean amphipods. Hydrobiologia 287: 131-145.

Humphreys, W.F. (1993). Stygofauna in semi-arid tropical Western Australia: a Tethyan connection? Mémoires de Biospéologie 20: 111-116.

Humphreys, W.F. (1995). Limestone of the east Kimberley, Western Australia - karst and cave fauna. Unpublished report to the Australian Heritage Commission and the Western Australian Heritage Committee. 190 pp.t xix. Western Australian Museum, Perth.

Humphreys, W.F. (1999a). Physico-chemical profile and energy fixation in Bundera Sinkhole, an anchialine remiped habitat in north-western Australia. Journal of the Royal Society of Western Australia 82: 89-98.

Humphreys, W.F. (1999b). Relict stygofaunas living in sea salt, karst and calcrete habitats in arid northwestern Australia contain many ancient lineages. In W. Ponder and D. Lunney (eds) The Other $99 \%$. The Conservation and Biodiversity of Invertebrates. Transactions of the Royal Society of New South Wales, Mosman 2088: 219-227.

Humphreys, W.F. (2000a). Chapter 30. The hypogean fauna of the Cape Range peninsula and Barrow Island, northwestern Australia. In H. Wilkens, D.C. Culver and W.F. Humphreys (eds). Ecosystems of the world, vol. 30. Subterranean ecosystems. Elsevier, Amsterdam: 581-601.

Humphreys, W.F. (2000b). Chapter 22. Relict faunas and their derivation. In H. Wilkens, D.C. Culver and W.F. Humphreys (eds). Ecosystems of the world, vol. 30. Subterranean ecosystems. Elsevier, Amsterdam: 417432.

Humphreys, W.F. (2000c). Karst wetlands biodiversity and continuity through major climatic change - an example from arid tropical Western Australia. In B. Gopal, W.J. Junk and J.A. Davis (eds). Biodiversity in wetlands: assessment, functions and conservation, vol. 1. Backhuys Publishers, Leiden: 227-258.

Jacobson, G. and Arakel, A. V. (1986). Calcrete aquifers in the Australian arid zone. In Proceedings of the International Conference on Groundwater Systems Under Stress. Australian Water Resources Council: Brisbane: 515-523.

Jaume, D., Boxshall, G.A. and Humphreys, W.F. (2001). New stygobiont copepods (Calanoida; Misophrioida) from Bundera sinkhole, an anchialine cenote on north-western Australia. Zoological Journal of the Linnean Society, London 133: 1-24.

Jaume, D. and Humphreys, W.F. (2001). A new genus of epacteriscid calanoid copepod from an anchialine sinkhole in northwestern Australia. Journal of Crustacean Biology 21: 157-169.

Jones, B.G. (1990). Cretaceous and Tertiary sedimentation on the western margin of the Eucla Basin. Australian Journal of Earth Science 37: 317-329.

Juberthie, C. and Decu, V. (eds)(1994). Encyclopedia Biospeleologica, volume 1. Société de Biospéologie, Moulis and Bucarest.

Juberthie, C. and Decu, V. (eds) (1998). Encyclopedia 
Biospeleologica, volume 2. Société de Biospéologie, Moulis and Bucarest.

Kriewaldt, M. and Ryan, G.R. (1967). Pyramid, W.A.: Western Australian Geological Survey 1:250 000 Geological series explanatory notes. Geological Survey of Western Australia, Perth.

Longley, G. (1992). The subterranean aquatic ecosystem of the Balcones Fault Zone Edwards Aquifer in Texas - threats from overpumping. In J.A. Stanford and J.J. Simons (eds). Proceedings of the First International Conference on Groundwater Ecology. American Water Resources Association, Bethesda, Maryland: 291-300.

Maczurad, M. and Murphy, M. (1997). Murrin Murrin Nickel Cobalt Project: Windarra Calcrete Deposit Exploration Report and Resource Estimates, volume 1. Anaconda Nickel Limited, Perth.

Malard, F. (1995). Contribution à l'étude biologique de la qualité des eau souterraines karstique: application à un site atelier Nord-Montpelliéain (bassin de la source du Lez). Doctoral thesis, Université Claude Bernard, Lyon.

Mann, A.W. and Deutscher, R.L. (1978). Hydrogeochemistry of a calcrete-containing aquifer near Lake Way, Western Australia. Journal of Hydrology 38: 357-377.

Mann, A.W. and Horwitz, R.C. (1979). Groundwater calcrete deposits in Australia: some observations from Western Australia. Journal of the Geological Society of Australia 26: 293-303.

Marmonier, P., Vervier, P., Gibert, J. and Dole-Olivier, M.-J. (1993). Biodiversity in ground waters. Trends in Ecology and Evolution 8: 392-395.

Marmonier, P., Ward, J.V. and Danielopol, D.L. (1997). Round Table 2 Biodiversity in groundwater/surface water ecotones: central questions. In J. Gibert, J. Mathieu and F. Fournier (eds). Groundwater/surface water ecotones: biological and hydrological interactions and management options. Cambridge University Press, Cambridge: 231-235

Messouli, M., Boutin, C. and Coineau, N. (1991). Phylogenie et biogeographie evolutive d'un groupe de Metacrangonyctidae, crustaces amphipodes stygobies du Maroc I - les especes du groupe Panousei. Mémoires de Biospéologie 18: 247-262.

Morgan, K.H. (1965). Hydrogeology of the East Murchison North Coolgardie Area. Western Australian Geological Survey Record 1965/16.

Morgan, K.H. (1993). Development, sedimentation and economic potential of palaeoriver systems of the Yilgarn Craton of Western Australia. Sedimentary Geology 85: 637-656.

Notenboom, J. (1991). Marine regressions and the evolution of groundwater dwelling amphipods (Crustacea). Journal of Biogeography 18: 437-454.

Passmore, J. R. (1983). Evaluation of groundwater supplies for Lake Way Project, Wiluna, in Resources and Responsibility ANZAAS, 53rd ANZAAS Congress, Perth, Western Australia, May 16-20, 1983, Section 3Hydrogeological Aspects of Resource Development, Paper 217: 1-9.

Peck, S.B. and Finston, T.L. 1993. Galapagos Island troglobites: the question of tropical troglobites, parapatric distributions with eyed sister species, and their origin by parapatric speciation. Mémoires de Biospéologie 20: 19-37.

Pesce, G.L., De Laurentiis, P. and Humphreys, W.F. (1996a). Copepods from ground waters of Western Australia. I. The genera Metacyclops, Mesocyclops, Microcyclops and Apocyclops (Crustacea Copepoda: Cyclopidae). Records of the Western Australian Museum 18: $67-76$.

Pesce, G.L., De Laurentiis, P. and Humphreys W. F. (1996b). Copepods from ground waters of Western Australia. II. The genus Halicyclops (Crustacea Copepoda: Cyclopidae). Records of the Western Australian Museum 18: 77-85.

Pesce, G. L. and De Laurentiis P. (1996). Copepods from ground waters of Western Australia. III. Diacyclops humphreysi n. sp. and comments on the Diacyclops crassicaudis-complex (Copepoda: Cyclopidae). Crustaceana 69: 524-531.

Pohlman, J. W., Cifuentes, L. A. and Iliffe, T. M. (2000). Food web dynamics and biogeochemistry of anchialine caves: a stable isotope approach. In $\mathrm{H}$. Wilkens, D.C. Culver and W.F. Humphreys (eds). Ecosystems of the world, vol. 30. Subterranean ecosystems. Elsevier, Amsterdam: 345-357.

Pohlman, J. W., lliffe, T. M. and Cifuentes, L A. (1997). A stable isotope study of organic cycling and the ecology of an anchialine cave ecosystem. Marine Ecology Progress Series 155: 17-27.

Poore, G.C.B. and Humphreys, W.F. (1992). First record of Thermosbaenacea (Crustacea) from the Southern Hemisphere: a new species from a cave in tropical Western Australia. Invertebrate Taxonomy 6: 719-725.

Poore, G.C.B. and Humphreys, W.F. (1998). First record of Spelaeogriphacea from Australasia: a new genus and species from an aquifer in the arid Pilbara of Western Australia. Crustaceana 71: 721-742.

Richoux, P. and Reygrobellet, J.L. (1986). First report on the ecology of the phreatic water beetles (Coleoptera, Dytiscidae). Entomologia Basiliensia 11: 371-384.

Rouch, R. and Danielopol, D.L. (1997). Species richness of microcrustacea in subterranean freshwater habitats. Comparative analysis and approximate evaluation. Internationale Revue gesamten Hydrobiologie 82: 121-145.

Sanders, C.C. (1973). Hydrogeology of a calcrete deposit on Paroo Station, Wiluna, and surrounding areas. Western Australian Geological Survey Annual Report 1972: 15-26.

Sanders, C.C. (1974). Calcrete in Western Australia. Western Australia Geological Survey Annual Report 1973: 12-14.

Schminke, H.K. (1974). Mesozoic intercontinental relationships as evidenced by bathynellid crustacea (Syncarida: Malacostraca). Systematic Zoology 23: 157164.

Schulz, H.N., Brinkhoff, T., Ferdelman, T.G., Marine, M.H., Teske, A. and Jorgensen, B.B. (1999). Dense populations of a giant sulfur bacterium in Namibian Shelf sediments. Science 284: 493-495.

Sket, B. (1986). Ecology of the mixohaline hypogean fauna along the Yugoslav coast. Stygologia 2: 317-338. 
Spangler, P.J. and Decu, V. (1998). Coleoptera aquatica. In C. Juberthie and V. Decu (eds). Encyclopedia Biospeleologica, volume 2: 1031-1046. Société de Biospéologie, Moulis and Bucarest.

Stanford, J.A. and Ward, J.V. (1993). An ecosystem perspective of alluvial rivers: connectivity and hyporheic corridor. Journal of the North American Benthological Society 12: 48-60.

Stock, J.H. (1980). Regression model evolution as exemplified by the genus Pseudoniphargus (Amphipoda). Bijdragen tot de Dierkunde 50: 105-144.

Taiti, S. Ferrara, F. and Iliffe, T.M. (1995). A new species of Haloniscus Chilton, 1920 from New Caledonia (Isopoda, Oniscidea). Crustaceana 68: 321-328.

Thurgate, M.E., Gough, J.S., Spate, A. and Eberhard, S.M. (2001). Subterranean biodiversity in New South Wales: from rags to riches. Records of the Western Australian Museum, Supplement No. 64: 37-47.

Uéno, S-I. (1996). New phreatobiontic beetles (Coleoptera, Phreatodytidae and Dytiscidae) from Japan. Journal of the Speleological Society of Japan 21: 150.

van de Graaff, W.J.E., Crowe, R.W.A., Bunting, J.A. and Jackson, M.J. (1977). Relict early Cainozoic drainages in arid Western Australia. Zeitschrift fur Geomorphologie 21: 379-400.

Ward, J.V. (1992). Aquatic Insect Ecology. Vol. 1. Biology and Habitat. Wiley, New York.

Ward, J.V., Malard, F., Stanford, J.A. and Gonser, T. (2000). Interstitial aquatic fauna of shallow unconsolidated sediments, particularly hyporheic biotopes. In $\mathrm{H}$. Wilkens, D.C. Culver and W.F. Humphreys (eds). Ecosystems of the world, vol. 30. Subterranean ecosystems. Elsevier, Amsterdam: 41-58.

Ward, J.V. and Palmer, M.A. (1994). Distribution patterns of interstitial freshwater meiofauna over a range of spatial scales, with emphasis on alluvial river-aquifer systems. Hydrobiologia 287: 147-156.

Ward, J.V. and Voelz, N.J. (1994). Groundwater fauna of the South Platte River System, Colorado. In J. Gibert, D.L. Danielopol, and J.A. Stanford (eds). Groundwater Ecology, Academic Press, London: 391-423.

Watts, C.H.S. and Humphreys, W.F. (1999). Three new genera and five new species of Dytiscidae (Coleoptera) from underground waters in Australia. Records of the South Australian Museum 32: 121-142.

Watts, C.H.S. and Humphreys, W.F. (2000). Six new species of Nirridessus and Tjirtudessus (Dytiscidae;
Coleoptera) from underground waters in Australia. Records of the South Australian Museum 33: 127-144.

Wilkens, H., Culver, D.C. and Humphreys, W.F. (eds). (2000). Ecosystems of the World, vol. 30. Subterranean Ecosystems. Elsevier, Amsterdam.

Williams, D.D. (1977). Movement of benthos during recolonization of temporary streams. Oikos 45: 306312.

Williams, W.D. (1983). On the ecology of Haloniscus searlei (Isopoda, Onsicoidea), an inhabitant of Australian salt lakes. Hydrobiologia 105: 137-142.

Williams, W.D. (1986). Amphipoda on land-masses derived from Gondwana. In L. Botosaneanu (ed.). Stygofauna Mundi: A faunistic, distributional, and ecological synthesis of the world fauna inhabiting subterranean waters (including the marine interstitial). E.J. Brill, Leiden: 553-559.

Williams, W.D, Boulton, A.J. and Taaffe, R.G. (1990). Salinity as a determinant of salt lake fauna: a question of scale. Hydrobiologia 197: 257-266.

Wilson, G.D.F. and Johnson, R.T. (1999). Ancient endemism among freshwater isopods (Crustacea, Phreatoicidea). In W. Ponder and D. Lunney (eds). The Other 99\%. The Conservation and Biodiversity of Invertebrates. Transactions of the Royal Zoological Society of New South Wales, Mosman: 264-268.

Wilson, G.D.F. and Keable, S.J. (1999). A new genus of phreatoicidean isopod (Crustacea) from the North Kimberley Region, Western Australia. Zoological Journal of the Linnean Society, London 126: 51-79.

Wilson, G.D.F. and Ponder, W.F. (1992). Extraordinary new subterranean isopods (Peracarida: Crustacea) from the Kimberley Region, Western Australia. Records of the Australian Museum 44: 279-298.

Woodward-Clyde. (1997a). Mining Area C hydrological investigations report (technical supporting document for the PER. BHP Iron Ore Pty Ltd., Perth.

Woodward-Clyde. (1997b). Newman satellite development mining of Orebody 23 below the watertable - consultative environmental review. BHP Iron Ore Pty Ltd., Perth.

Yager, J. and Humphreys, W.F. (1996). Lasionectes exleyi, sp. nov., the first remipede crustacean recorded from Australia and the Indian Ocean, with a key to the world species. Invertebrate Taxonomy 10: 171-187.

Manuscript received 28 March 2000; accepted 5 July 2000.

Edited by M.S. Harvey. 